\title{
Küresel Finansal Krizinin Devlet Borçlarına Etkisi: Gelişmiş ve Gelişmekte Olan Ülkeler Açısından Bir Değerlendirme1
}

\author{
Birol KARAKURT, Department of Public Finance, Faculty of Economics and Administrative Sciences, \\ Karadeniz Technical University, Turkey; e-mail: birolkarakurt@ktu.edu.tr \\ Tekin AKDEMIR, Department of Public Finance, Faculty of Political Sciences, Yildirim Beyazit University, \\ Turkey; e-mail: tekinakdemir@hotmail.com
}

\section{The Effects of the Global Crisis on Public Debt: An Assessment on Advanced and Developing Countries ${ }^{2}$}

\begin{abstract}
Economic and financial crises both of which the severity and intensity have gradually increased with the globalisation have triggered fiscal imbalances in many countries. One of them is the crisis of 2008. While in previous crises countries have managed their debt stock positively in some way, the global recession followed by the financial crisis of 2008 has led to increases in debt stock enormously. However, there is a big divergence in the impact of the crisis on the advenced countries and emerging market countries. Emerging market countries, whose have more favorable macroeconomic indicators in the pre-crisis period were successfully able to manage to eliminate the adverse effects of the global financial crisis. By contrast, this has notably threatened the developed countries where the economic policy framework is unsatisfactory or relatively poor. This study deals with the effects of the global financial crisis on public debt by comparing countries' financial positions based on macroeoconomic indicators in pre- and post-crisis period.
\end{abstract}

Keywords $\quad$ : Global Crisis, Debt Crisis, Sovereign Debt Crisis, European Debt Crisis.

JEL Classification Codes : $\quad$ E6, E62, F34, G01, H63.

I Bu makale Sosyoekonomi Derneği ile Hacettepe Üniversitesi Piyasa Ekonomisini ve Girişimciliği Gelişstirme Merkezi tarafindan Almanya'nın Münih şehrinde, 29-30 Ekim 2015 tarihlerinde düzenlenen "Birinci Uluslararası Sosyoekonomi Derneği Yıllık Buluşması"nda sunulan çalışmanın gözden geçirilmişs ve genişletilmiş halidir.

2 This article is the revised and extended version of the paper presented in "First International Annual Meeting of Sosyoekonomi Society" which was held by Sosyoekonomi Society and CMEE - Center for Market Economics and Entrepreneurship of Hacettepe University, in Munich/Germany, on October 29-30. 


\section{$\ddot{O} \mathbf{z}$}

Globalleşme ile birlikte hem şiddeti hem de sıklığı giderek artan finansal ve ekonomik krizler, pek çok ülkede mali dengesizliklere neden olmuştur. Bunlardan biri de, 2008 krizidir. Daha önceki krizlerde ülkeler belli bir ölçüde de olsa borç stoklarını olumlu koşullar altında yönetirken, 2008 krizi ve bu krizin küresel boyutta bir durgunluğa dönüşmesi kamu borç stokunda önemli artışlara neden olmuştur. Ancak, krizin gelişmiş ülkeler ve yükselen piyasa ekonomilerine etkileri konusunda önemli farklılıklar vardır. Kriz öncesi dönemde makroekonomik göstergeleri daha iyi durumda olan yükselen piyasa ülkeleri, krizin etkilerini bertaraf etmede daha iyi bir performans sergilemişlerdir. Buna karşın, ekonomi politikası çerçevesi nispeten olumsuz olan ülkelerde kriz karşıtı politikalar yeterince tatminkâr sonuçlar doğurmamıştır. Bu çalışma, ülkelerin kriz öncesi ile kriz sonrası mali pozisyonlarını makroekonomik göstergeleri temel alarak karşılaştırmak suretiyle, krizin kamu borçları üzerindeki etkilerini ele almaktadır.

Anahtar Sözcükler $\quad$ : Global Kriz, Borç Krizi, Devlet Borç Krizi, Avrupa Borç Krizi.

\section{Giriş}

2008 yılında ABD'de başlayan finansal kriz, ekonomik ve finansal küreselleşmenin bir sonucu olarak diğer ülkelere hızlı bir şekilde yayılmış; geçen zaman içinde şiddeti artarak gelişmiş ve gelişmekte olan birçok ülkeyi etkisi altına almıştır. Eylül 2008'de Lehman Brothers'in iflasıyla küresel nitelik kazanan finansal kriz 2009 yılında dünya genelinde ekonomilerde ciddi daralma meydana getirmiştir. Küresel ekonomik ve finansal sisteme daha fazla entegre olan ülkeler krizden daha fazla etkilenirken, ekonomik ve mali açıdan nispeten dışa kapalı olan ülkeler krizden daha az etkilenmişlerdir. Dolayısıyla küreselleşen ekonomik ve finansal sisteme bağlılık arttıkça, ülkeler krizlerin etkilerine daha açık hale gelmişlerdir.

Finansal krizler, ülkeleri finansal ve ekonomik yönden etkilemektedirler. Finansal yönden etki, krizin borçlanma faizleri vb. aracılığıyla (daha çok finansal sistem yoluyla) diğer ülkeleri etkilemesi şeklindedir. Ekonomik yönden etki ise, krizin diş ticaret vb. yollarla diğer ülkeleri etkilemesi şeklindendir. Buradan hareketle, küresel kriz gelişmiş ülkeleri daha çok finansal yönden etkilerken; gelişmekte olan ülkeleri, yükselen piyasa ekonomilerini ve az gelişmiş ülkeleri ise daha çok ekonomik yönden etkilemiştir.

Küresel finansal krize kadar gelişmekte olan ülkelerde borç yönetimi olumlu koşullar altında işlemiştir. Kriz öncesi dönemde (2000-2007 dönemi), pek çok ülke düşük faizle borçlanma olanağına sahip olmuş ve borcunun vadesini de uzatabilmiştir. Ancak, 1929 krizinden sonraki en ağır kriz olarak nitelendirilen küresel finansal kriz, borçlanma dinamiklerini etkilemiş ve tüm dünyayı az ya da çok etkisi altına almıştır. Krizden etkilenen hemen hemen her ülke genişletici politikalar uygulayarak, krizin negatif etkilerini bertaraf etme yoluna gitmiştir. Bu çerçevede, kamu harcamaları arttırılmış, vergiler azaltılmış veya parasal genişleme yoluyla yurt içi faizleri azaltılmaya çalışılmıştır. Kamu ve özel bankaların yeni finansman ihtiyacı (banka kurtarma), kapsamlı ekonomik canlandırma paketleri ile birleştiğinde uzun dönemde -başlangıçta gelişmiş ülkeler içinbüyük bütçe açığı ve çı̆̆ gibi büyüyen kamu borcu ortaya çıkmıştır. Özellikle de bazı 
bankaların borçlarının kamulaştırılmasıyla birlikte, kamu borcu seviyesi çok ciddi şekilde yükselmiştir. Buna bağlı olarak da, borcun geri ödenmesiyle ilgili endişeler artmıştır. Krizin, reel ekonomi üzerinden gelişmekte olan ülkelere etkilerinin görülmesiyle birlikte, bu ülkeler de genişletici politikalar uygulamaya başlamış ve sonuçta bütçe açığı ve kamu borç stoku artmıştır.

Krizden önce makroekonomik göstergeleri olumlu seyreden ülkeler, krizin etkilerini bertaraf etmede daha başarılı olurken bütçe, cari denge ve borç oranları açısından zayıflık gösteren ülkelerin krize karşı önlemleri nispeten başarısız olmuş ve diğer yandan borçlarında da önemli düzeyde artışlar gözlenmiştir. PIIGS ${ }^{3}$ ülkeleri olarak nitelendirilen Avrupa çevre ülkelerinin kamu borcu, krizden sonra hızlı bir biçimde artarken gelişmekte olan veya yükselen piyasa ekonomilerinin borçları artsa dahi ülkelerin krizden önceki mali performansı bu ülkelerde potansiyel bir borç krizini engellemiştir. Bu değerlendirmelerden hareketle, bu çalışmanın tezi, küresel finansal krizin tüm ülkelerde kamu borcunu artırdığıdır. Bu tezden hareketle çalışmanın amacı, küresel krizin yayılma mekanizması ve etki kanallarını ortaya koyarak ülke borçlarına etkisini analiz etmektir.

\section{Küresel Finansal Krizin Nedenleri ve Gelişimi}

ABD'de teknoloji balonunun patlamasından sonra ${ }^{4}$, FED'in düşük faiz politikası sonucunda faiz oranları 2000'li yılların başında oldukça düşük düzeye çekilmiştir. Faizin düşmesi ile birlikte daha kârlı yatırım alanları arayan finansal kurumlar, kredibilitesi düşük olan diğer bir ifadeyle geri ödeyememe riski çok yüksek olan ve bu nedenle daha önce kendilerine kredi verilmeyen tüketicilere (subprime/eşik altı) kredi vermeye başlamışlardır. Kamunun (devletin), halkı ev sahibi yapma politikası da bu gruplara kredi verilmesini teşvik etmiş ve dolayısıyla ev sahibi olmaları mümkün olmayan düşük gelirli kişilere subprime (eşik altı) mortgage kredileri verilmiştir. Değişen/bozulan borç verme standartları sonucu artan krediler, konut talebini ve dolayısıyla konut fiyatlarını da arttırmıştır (Lander vd. 2009: 2; De Tombe, 2013: 2). Yüksek riskli gruplara düşük faizle ipotekli konut kredilerinin verilmesi konut talebinin artırmış, artan konut talebinin konut fiyatlarına yansımasıyla birlikte, konut sektöründe bir balon oluşmuştur.

3 PIIGS; Portekiz, Irlanda, İtalya, Yunanistan ve İspanya gibi krizden en çok etkilenen AB ülkelerini ifade etmek için kullanılmaktadır.

4 ABD'de 1990'ların sonunda teknoloji şirketlerine olan ilgi, bu şirketlerin halka açılmalartyla birlikte şirketlerinin piyasa değerlerinde esaslı bir yükselmeye yol açmıştır. Fakat, bu ilgi patlaması yenilikçi bir gelir modeliyle desteklenmediğinden şirketlerin gerçek değerini belirten defter değerleri ile piyasa değerleri arasında fark ortaya çıkmıştır. Temmuz 1999 ve Mart 2000 arasında \%50'nin üzerinde değerlenen teknoloji şirketlerinin değeri daha bir yıl dolmadan \%40 civarında değer kaybetmiş ve Nasdaq Borsası çökmüştür. Bu durum uzmanlarca 'teknoloji balonunun patlaması' olarak değerlendirilmiștir. 
Mortgage kredilerinin menkul kıymetleştirme yoluyla değerli kâğıtlara dönüştürülerek küresel piyasaya ihraç edilmesi ile risk piyasaya intikal ettirilmiştir. $\mathrm{Bu}$ durum, daha fazla mortgage kredisi verilmesine olanak sağlamıştır (Haffner, 2008: 339). Finansal kuruluşlar üzerindeki denetim ve gözetimin zayıf olması, kredi derecelendirme kuruluşlarının mortgage kredisine dayalı menkul kıymetleri değerlendirmede yetersiz oluşu ve riski tam olarak göster(e)memesi de (Baily vd., 2008: 34-41) saydamlığı azaltarak mortgage kredilerinin verilmesini kolaylaştırmıştır. İlave olarak, mortgage kredilerinin kârlı oluşu finansal kuruluşları yeni arayışlara itmiş ve pek çok mortgage kredisi türevleri geliştirilmiştir. Örneğin, değişken faizli ipotekli konut kredisi (ARM), başlangıç faizleri ilk yıllar için sabit ve düşük krediler iken daha sonraki yıllarda piyasa faiz oranının durumuna göre yenilenen ve faiz oranı artırılan krediler olduğundan; bu durum, kredi kullanan konut sahibi tarafından fark edilmemiştir (Baily vd., 2008: 17; Murphy, 2008: 1).

Faizler düşük iken ödeme güçlüğü çekmeyen tüketici grupları, değişen ve artan faizlerle birlikte kredi taksitlerini geri ödemede güçlüğe ve temerrüde düşmüşlerdir. $\mathrm{Bu}$ duruma FED'in giderek büyüyen konut balonunu soğutmak için faiz artırımına gitmesinin de eklenmesi ile konut talebi ve dolayısıyla konut fiyatları düşmeye başlamıştır. Düşen fiyatlar ise finansal sistemde sorunlara yol açarak finansal krizin başlamasına neden olmuştur (De Tombe, 2013: 2).

\section{Küresel Finansal Krizin Yayılması}

2008 küresel finansal krizi sonucunda özellikle gelişmiş ülkeler 1929 buhranından sonraki en büyük durgunluğu yaşamışlardır. Söz konusu kriz, daha önce yaşanan finansal krizlerden farklı özellikler göstermiştir. Daha önceki krizler bölgesel düzeyde gelişmiş ve daha çok gelişmekte olan ülkeleri etkilemişken, yayılma alanları da genellikle sınırlı kalmıştır. Fakat 2008 krizi küresel ekonomiye yön veren bir ülkede ABD'de- patlak vermiş ve küresel niteliğe bürünerek başta gelişmiş ülkeler olmak üzere hemen hemen tüm ülkeleri etkilemiştir (Hernandez \& Gamarra, 2011: 129).

\subsection{Krizin Gelişmiş Ülkelere Yayılması}

Krizin yayılması, ilk etapta finansal yolla olmuş ve daha çok gelişmiş ülkeleri etkilemiştir. Krizin, finansal kanallarla ülkeleri etkilemeye başlaması krizin başladığı evrelerde daha yoğun olmuştur. Gelişmekte olan ülkelerin bankalarının elinde mortgage'a dayalı menkul kıymetler bulunmadığından söz konusu menkul kıymetler finansal olarak risk teşkil etmemiş ve başlangıçta, krizin finansal etkisinden gelişmekte olan ve az gelişmiş ülkeler hemen hemen hiç etkilenmemişlerdir (Serieux, 2009: 7; Boorman, 2009: 3). Fakat, toksik (zehirli-çürük) varlıklar olarak da adlandırılan mortgage'a dayalı menkul kıymetler, finansal olarak oldukça genişleyen ve küreselleşen ABD ve Avrupa banklarının portföylerinde (ellerinde) fazlası ile yer bulmuştur. $\mathrm{Bu}$ toksik kağıtlar, menkul kıymetleştirme ile uluslararası piyasalara ihraç edilmiş ve başta İngiltere olmak üzere pek çok Avrupa ülkesi bankalarının elinde mortgage kredisine dayanan önemli miktarda 
değerli kağıt birikmiştir. Krizle birlikte değeri düşen ve ikincil piyasada işlem görmeyen (geçerliliğini yitiren) bu değerli kâğıtlar başta çıkış noktası olan ABD olmak üzere bütün Avrupa'yı etkilemiştir (Brok \& Langen, 2012: 191).

Finansal krizle birlikte, ellerinde önemli miktarda toksik kâğıt bulunan birçok banka riske zayıf bilançolarla yakalanmış ve büyük kayıplara uğramışlardır. Kriz, toksik kâğıtların değerine ilişkin belirsizlik nedeniyle bankaların borçlanmalarını daha da güçleştirmiştir (Eser \& Ela, 2015: 211). Diğer yandan krizde başlayan riskten kaçış ve kredi daralması da gelişmiş ülkeleri etkileyen bir başka unsur olmuştur (Abreu vd., 2009: 3). Krizle birlikte finansal sistemleri bozulan ve bankaları iflas eden gelişmiş ülkeler, banka kurtarma ve devletleştirme politikalarını uygulamaya koymuşlardır. Sistematik bankacılık krizi yaşayan ülkeler, finansal krizin etkisini daha çok hissetmişlerdir. Nitekim kriz döneminde, bankalara yapılan yardımları gösteren Tablo 1 aracılığıyla krizin gelişmiş ülkelere etkisini daha açık bir şekilde ortaya koymak mümkündür.

Tablo: 1

\section{Bankalara Yapılan Yardımların GSYH'ya Oranı (\%)}

\begin{tabular}{|c|c|c|c|c|c|}
\hline Ülkeler & $\begin{array}{l}\text { Sermaye } \\
\text { yardımı }\end{array}$ & $\begin{array}{l}\text { Varlık alımı ve } \\
\text { borç verme }\end{array}$ & $\begin{array}{c}\text { Merkez Bankası } \\
\text { yardımı }\end{array}$ & $\begin{array}{l}\text { Likidite yardımı ve } \\
\text { diğer destekler }\end{array}$ & $\begin{array}{c}\text { Borçlara verilen } \\
\text { garantiler }\end{array}$ \\
\hline ABD & 4,0 & 6,0 & 1,1 & 31,3 & 31,3 \\
\hline Almanya & 3,7 & 0,4 & 0,0 & 0,0 & 17,6 \\
\hline Fransa & 1,2 & 1,3 & 0,0 & 0,0 & 16,4 \\
\hline Birleşik Krallık & 3,5 & 13,8 & 12,9 & 0,0 & 17,4 \\
\hline İtalya & 1,3 & 0,0 & 0,0 & 2,5 & 0,0 \\
\hline İspanya & 0,0 & 4,6 & 0,0 & 0,0 & 18,3 \\
\hline İlanda & 5,3 & 0,0 & 0,0 & 0,0 & 257 \\
\hline Japonya & 2,4 & 6,7 & 0,0 & 0,0 & 3,9 \\
\hline Yunanistan & 2,1 & 3,3 & 0,0 & 6,2 & 11,6 \\
\hline Portekiz & 2,4 & 0,0 & 0,0 & 0,0 & 12,0 \\
\hline
\end{tabular}

Kaynak: IMF, 2009: 7.

Tablo 1'e bakıldığında, gelişmiş ülkelerin bankalara yaptığı sermaye yardımlarının bu ülkelerin GSYH'sının önemli bir yüzdesini oluşturduğu görülmektedir. Sermaye yardımlarının yanı sıra, finansal kurumların likit olmayan varlıklarının satın alınması, bu kurumlara doğrudan borç verilmesi, merkez bankası yardımları ve bankacılık kesiminin borçlarına verilen garantiler; krizin en önemli maliyetlerinden birinin, bankaların kurtarılması için verilen destekler olduğunu göstermektedir. Kriz döneminde bankacılık sektörünün güçlendirilmesine yönelik parasal önlemler, gelişmiş ülkelerin kamu maliyesi üzerinde önemli maliyetlere neden olurken; banka borçlarının kamulaştırılması, kamu borcunun yüksek seviyelere çıkmasına neden olmuştur (Ulusoy vd, 2013: 263). Diğer yandan finansal sektörde meydana gelen çöküş reel sektörü de etkilemiştir. Finansal sektörde yaşanan kredi daralması ve artan borçlanma maliyetleri gelişmiş ülkelerde yurtiçi talebi azaltmıştır. Bunun sonucunda ise fiyatlarda ve büyümede düşüş eğilimi gözlenmiştir (Nissanke, 2009: 7). Küresel kriz sonrasında ekonomisi küçülen bir çok gelişmiş ülkenin aynı zamanda bankalara kaynak aktarmak zorunda kalması, bu ülkeleri oldukça güç bir durumla karşı karşıya bırakmıştır. Bu açıdan Tablo 1, krizin ülkeler üzerindeki vahametini görebilmek adına önemlidir. 
Kriz tüm ülkeleri, bölgeleri ve nüfus gruplarını aynı ölçüde ya da aynı zaman diliminde etkilememiştir. Krizin yayılma kanaları ve gelişimi ülkeler itibariyle farklılık arz etmekle birlikte, reel ekonomi üzerinde ciddi maliyetleri söz konusu olmuştur (Schularick, 2012: 6). Bu konuda son dönemde yapılan çalışmalar, krizin üretim üzerinde uzun dönemli negatif etkilere sahip olduğuna işaret etmiştir. Bu çalışmalara göre, finansal kriz, GSYH'nın \%7,5 ile \%10 arasında değişen oranlarda üretim kaybına yol açmıştır (Schularick, 2012: 6). Finansal krizin, varlık fiyatları, üretim ve istihdam üzerinde derin ve zamana yayılan (kalıcı) etkileri de söz konusudur. Nitekim krizle birlikte işsizlik oranlarında yükseliş meydana gelirken, konut fiyatlarında esaslı bir düşüş gerçekleşmiştir. Finansal kriz nihayetlendiğinde ise, bütçe açığı ve kamu borç stoğunda büyük bir artış görülmüştür (Reinhart \& Rogoff, 2009).

\subsection{Krizin Gelişmekte Olan Ülkelere Yayılması}

Gelişmiş ülkelerde başlayan kriz, ticaret ve sermaye akımları aracılığıyla gelişmekte olan ülkelere yayılmıştır. Gelişmekte olan ülkeler dışa açıklık oranları ve küresel ekonomiye entegre olma düzeylerine bağlı olarak, krizin etkisine daha hızlı ve daha güçlü şekilde maruz kalmışlardır (Gurtner, 2010). Avrupa’ya finansal yolla yayılan kriz, gelişmekte olan ülkelere ekonomik yolla yayılmıştır. Gelişmekte olan ülkeler kriz öncesi yıllarda sürdürdükleri sağlam para ve maliye politikaları sayesinde, krize geçmiş krizlerde olduğundan daha güçlü ekonomik altyapı ile yakalanmışlar ve krizin başlangıcında finansal olarak çok etkilenmemişlerdir. Bu aşamada çok az ülke krizden etkilenmiştir. Küresel krizden etkilenen ülkelerin çoğu ise; Avrupa ve ABD bankalarının sahip oldukları toksik kâğıtlara yaptıkları yatırımlar nedeniyle bankacılık sistemleri doğrudan ya da dolaylı olarak etkilenen Doğu Avrupa ve Güneydoğu Asya ülkeleri ile hızlı gelişen ve kendi piyasalarında gayrimenkul kıymet balonlarının oluştuğu ülkelerdir (Hernandez \& Gamarra, 2011: 129).

Gelişmekte olan ülkeler, ihracattaki keskin daralma ve varlık fiyatları aracılığıyla küresel krizden krizin ilerleyen aşamalarında etkilenmişlerdir. Kriz, ABD ve bazı Avrupa ülkelerinde milli gelirin azalmasına ve ithalat taleplerinin düşmesine neden olmuştur. Bu noktada finansal etki ekonomik etkiyi adeta tetiklemiştir. Diğer bir deyişle finansal yönden etkilenen gelişmiş ülkeler, ithalat talebini azaltarak, gelişmekte olan ülkelerin ihracat gelirlerinin azalmasına ve krizin ekonomik olarak gelişmekte olan ülkelere yayılmasına yol açmıştır. Başta ABD olmak üzere gelişmiş ülkelerin milli gelirleri ve dolayısıyla ithalat taleplerinin düşmesi de, gelişmekte olan ülkelerin ihracat gelirlerini azaltmıştır. Örneğin, krizin ilk aşamasında AB'nin en büyük ülkeleri olan Almanya, Fransa ve Birleşik Krallık'ın gıda ve canlı hayvan ithalatı \%30 azalmıştır (Meyn \& Kennan, 2009: 1). Bu durum, gelişmekte olan ülkelerdeki ihracata yönelik endüstrileri etkileyerek üretim ve istihdamın azalmasına neden olmuştur (Abreu vd., 2009: 3).

İhracat gelirlerini azaltan bir başka unsur da, emtia fiyatlarındaki düşüştür. Emtia fiyatlarındaki düşüş, ihracat geliri azalan ülkeleri ihraç mallarının fiyatlarındaki azalma yoluyla etkilemiş ve bu ülkelerin ihracat geliri daha da düşmüştür (Hernandez \& 
Gamarra, 2011: 130). Bu durumu, bazı gelişmekte olan ve yükselen piyasa ülkelerinin mal ve hizmet ihracatlarındaki yıllık değişimlerin gösterildiği Grafik 1'den de açıkça görmek mümkündür.

\section{Grafik: 1}

\section{Gelişmekte Olan Bazı Ülkelerin Mal ve Hizmet İhracatının Yıllık Değişimi (\%)}

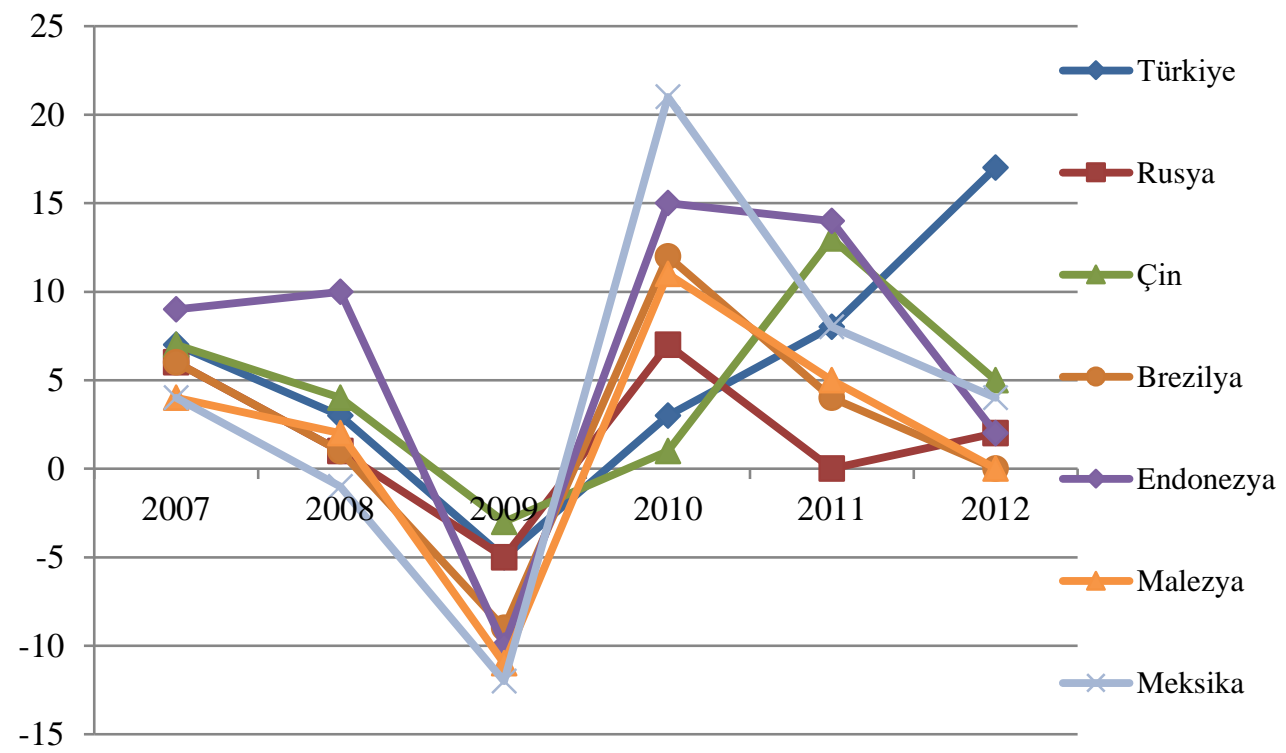

Kaynak: World Databank, <http://databank.worldbank.org/data/views/reports/tableview.aspx\#>.

Grafik 1, küresel finansal krizin uluslararası ticareti 2008 yılından itibaren etkilediğini ve özellikle de 2009 yılında ticaret hacminde esaslı bir daralmaya neden olduğunu göstermektedir. Bu durum ülkelerin ihracat gelirlerinin düşmesine ve mal ve hizmetlere olan talebin azalmasına neden olmuştur. Dolayısıyla küresel kriz ülkelerin mal ve hizmetlerine talebi iki yönden azaltmıştır. Birincisi, ihracat yoluyla, ikincisi ise krizden sonra ülkelerde düşen iç talep yoluyladır. Krizle birlikte, ihracat hacminin uluslararası ölçekte daralması gelişmekte olan ülkeleri olumsuz yönde etkilese de; emtia fiyatlarındaki düşüş, yüksek miktarda ithalat yapan kimi ülkelerin faydasına olmuştur. Bu durum, özellikle yüksek petrol ve gıda fiyatları cari işlemler dengesi üzerinde büyük bask1 oluşturan az gelişmiş ülkeler için geçerlidir (Audiguier, 2012: 10).

Küresel krizin gelişmekte olan ülkelere diğer yayılma mekanizması, özel sermaye akımlarının azalması sonucu olmuştur. Krizin, gelişmiş ülkelerden gelişmekte olan ülkelere yayılmasının en önemli kanallarından biri özel sermaye akımlarıdır. Bu etki, hem sermaye hacmi hem de maliyetler üzerinden kendini göstermiştir (Griffith-Jones \& 
Ocampo, 2009: 5). Literatürde, sermaye akımlarını çeken en önemli faktör olarak reel GSYH büyümesi gösterilmektedir. İlave olarak, kurumsal karlılığı artıran yüksek üretim artışı, hisse senedi yatırımlarının getirisindeki artış, borç servisi kabiliyetindeki gelişme, borçlanma ihtiyacını azaltan düşük kamu harcaması veya vergi gelirlerindeki önemli artışlar da sermaye akımlarını teşvik etmektedir. Buna karşın, yabancı sermaye arzı, küresel finansal koşullar, dış borç/GSYH oranındaki yükseliş, kamu borçlarının GSYH içindeki payının artması ve kurumsal kalitede yaşanan aşınmalar ise sermaye akımlarını azaltan hatta sermaye çıkışına yol açan faktörler olarak öne çıkmaktadır (Koepke, 2014: 4). Küresel kriz sonucu oluşan panik ve riskten kaçma eğilimi; sermaye arzında daralmaya yol açtığından, makroekonomik performansı kötü olan ülkelerden sermaye çıkışı olmuştur (Griffith-Jones \& Ocampo, 2009: 5). Krizin finansal sektörde neden olduğu kırılganlıklar, özel sermaye hareketleri, özellikle de borç akışında bir daralmaya yol açarken, bazı ülkelerde 2008'den sonra işçi döviz gelirleri de azalmıştır (Hernandez \& Gamarra, 2011: 130). Bu durum özellikle borçluluk oranı yüksek, cari açık veren ve vadesi gelen borçlarını ödeyebilmek amacıyla finansmana ihtiyaç duyan ülkeler için geçerli ve zorlayıcı olmuştur (Boorman, 2009: 4).

\section{Tablo: 2}

\section{Gelişmekte Olan Ülkelere Net Sermaye Akımları (Milyar Dolar)}

\begin{tabular}{|c|c|c|c|c|c|c|c|c|c|}
\hline Sermaye Akımı & 2005 & 2006 & 2007 & 2008 & 2009 & 2010 & 2011 & 2012 & 2013 \\
\hline Net Özel ve Resmi Sermaye Akımı* & 442.9 & 705,8 & $1.180,2$ & 707.7 & 675.4 & $1,094.8$ & $1,025.6$ & $1,063.1$ & $1,184.4$ \\
\hline Net DYY & 253.6 & 398,0 & 559,4 & 480.5 & 345.5 & 479.7 & 571.4 & 541.5 & 574.2 \\
\hline İşçi Dövizleri** & 180,0 & 213,6 & 259,7 & 213,6 & 259,7 & 301,0 & 285,0 & 315,6 & 355,0 \\
\hline
\end{tabular}

Tablo 2'den görüldüğü üzere, krizle birlikte gelişmekte olan ülkelere sermaye akımları azalmıştır. Net özel ve resmi sermaye akımlarında azalma krizin yaşandığı 2008 ve 2009 yıllarında geçerli iken, doğrudan yabancı sermaye yatırımlarındaki azalma ise 2009 ve 2010 yıllarında daha belirgindir. Dikkat edilmesi gereken bir diğer husus, uluslararası piyasada krizden önce koşulların olumlu seyretmesi nedeniyle bu göstergelerde krize kadar kesintisiz bir artışın olduğudur. Krizden sonra sermaye akımlarında meydana gelen azalma, gelişmekte olan ülkelerde menkul kıymetler borsasında değer kayıplarının yaşanmasına ve döviz kurlarının yükselmesine neden olmuştur (Abreu vd., 2009: 4). Ticaret hacminin tekrar arttığı, büyümenin pozitif, risk algısının düşük ve dolayısıyla krizin etkisinin geçtiği yönünde güçlü emarelerin olduğu 2010 yılında ise, net sermaye akımlarında önemli bir artış yaşanmıştır.

Krizin gelişmekte olan ülkelere yayılma mekanizmalarından bir diğeri de, işçi dövizi girişlerindeki azalma aracılığıyla kendini göstermiştir. İşçi dövizleri miktar olarak az olsa da bazı ülkeler için önem arz etmektedir. Çünkü birçok ülke işçi dövizlerinin azalmasından önemli biçimde etkilenmiştir. Krizle birlikte gelişmiş ülkelerde işsizlikte yaşanan artış nedeniyle işçi dövizleri de 2009 yılında azalmıştır (Hernandez \& Gamarra, 2011: 130). Bu durum Tablo 2'den de açıkça görülebilmektedir. Kriz öncesinde, gelişmiş 
ülkelerdeki yüksek büyüme oranları ve yatırımlar nedeniyle işçi dövizleri kriz dönemine kadar artmış, ancak krizle birlikte düşmüştür. Örnek vermek gerekirse krizle birlikte inşaat faaliyetlerindeki azalmalar sonucunda ABD'den Meksika'ya olan işçi dövizi akımı azalmıştır. Bütün olarak, krizden sonra işçi dövizleri azalmış ve bu durum küresel krizin gelişmekte olan ülkelere yayılmasında etkili olan faktörlerden biri olarak ortaya çıkmıştır (Griffith-Jones \& Ocampo, 2009: 4-5).

Krize karşı açıklanan paketler, ülkelerin sahip olduğu mali pozisyona bağlı olarak değişiklik göstermiştir. Krizin, kamu sektörü dengesi üzerinde büyük etkilerinin yanı sıra, yankı uyandıran politik sonuçları da olmuştur. Küresel kriz, gelişmiş ülkelere genel olarak finansal sistem aracılığıyla yayılmıştır. Krizin olumsuz etkileri, finansal sistemleri ABD ile entegre olmuş Avrupa ülkelerinde daha fazla görülmüştür. Batma noktasına gelen bazı bankalara ya devletler tarafından yardım edilmiş ya da bu bankalar devletleştirilmiştir. Bu noktada finans sektörünün krizi, bankacılık sistemi aracılığıyla kamu kesimine geçmiş ve finansal kriz bazı $\mathrm{AB}$ ülkelerinde kamu borç krizine dönüşmüştür. Gelişmekte olan ülkelerde ise, kriz etkisini ikinci etapta ve ekonomik etki şeklinde göstermiştir. Krizle birlikte gelişmiş ülkelerdeki ithalat talebinin azalması, gelişmekte olan ülkelerin ihracatını hacim ve fiyatça azaltıştır. Bunun yanı sıra sermaye akımı ve işçi dövizlerindeki azalma da bu ülkeleri olumsuz yönde etkilemiştir. Fakat gelişmekte olan ülkeler, gelişmiş ülkelere göre ekonomik açıdan daha olumlu koşullara sahip olduklarından ve mali alanda manevra yapabilme kabiliyetleri daha fazla olduğundan dış şoklara karşı daha dayanıklı kalabilmişlerdir.

\section{Küresel Krizin Kamu Borçlarına Etkisi}

Küresel kriz öncesinde, piyasalarda finansal koşullar olumlu seyretmiş ve ülkeler oldukça iyi koşullar altında krediye erişim imkânına sahip olmuşlardır. Emtia fiyatlarındaki yükseliş ve ihracat hacmindeki artış ülkelerin ihracat gelirlerini arttırırken, genel olarak büyüme oranları da pozitif görünüm arz etmiştir. Kriz öncesi dönemde var olan bu olumlu koşullara karşın, ülkelerin makroekonomik performansı yurtiçi ekonomik koşullar ve izlenen ekonomi politikaları çerçevesinde şekillenmiştir. Bazı ülkeler yapısal reformlar, sıkı ekonomi yönetimi, borçları azaltma ve bütçe açıklarını düşürme çabaları neticesinde krize daha iyi iç ve dış ekonomik göstergelerle girerken, bazılarında makroekonomik göstergeler olumsuz seyretmiş ve yüksek oranda bir borçluluk söz konusu olmuştur. Özellikle yükselen piyasa ülkeleri, kriz öncesinde borç portföyünün kırılganlığını azaltmışlardır. Borçların ortalama vadesi uzamış, yeni ve uzun vadeli borç bulma imkânları gelişmiş dolayısıyla pek çok ülke krize daha düşük borç çevirme riski ile girmiştir (Gooptu \& Braga, 2010). Örnek vermek gerekirse, krizden önce Rusya, Ukrayna, Arjantin ve Türkiye gibi birçok ülkede enflasyon oranı düşmüştür. Türkiye, krizden önce bütçe dengesini iyileştirirken Şili, Nijerya ve Rusya gibi ülkeler cari işlemler ve bütçe dengelerini güçlendirmişlerdir. Bu süreçte birçok ülke krize düşük borç oranı (borç/GSYH oranı) ile girdiği gibi, pek çok ülkede bütçe fazla vermiş ve GSYH'nın \%60'ının altında borç seviyesi söz konusu olmuştur. Bu da, anılan ülkelerin krize daha güçlü mali yapıyla cevap vermelerine olanak tanımıştır. İlave olarak, birçok ülkede dış borçların GSYH'ya 
oranı ülkelerin yüksek GSYH artışı ve döviz kurundaki düşmeler neticesinde yerli paranın değer kazanması ile azalmıştır (Gooptu \& Braga, 2010: 209; Van Doorn vd., 2011: 175177).

Gelişmekte olan birçok ülkenin aksine, Avrupa'da bulunan bazı ülkelerin ve büyük Güney Asya ülkelerinin makroekonomik göstergeleri kriz öncesi dönemde pek olumlu olmadığından, gelişmekte olan ülkeler krizden önce borçlarını düşürüyorken bu ülkelerin borçları artmıştır. Yani bu ülkeler; büyük bütçe açıkları, yüksek seviyede kamu borcu, yüksek cari açık ve düşük döviz rezervi sorunuyla karşı karşıya kalmış ve küresel krize zayıf mali pozisyon ile yakalanmışlardır (Griffith-Jones \& Ocampo, 2009: 10). Özellikle Doğu Avrupa'daki geçiş ekonomilerinin ve Güney Asya ülkelerinin, krizden olumsuz şekilde etkilenmeleri neticesinde ekonomik büyümeleri sert bir şekilde düşmüştür. Kriz öncesi olumlu mali tablo, 2009 yılına gelindiğinde hızla bozulmuş ve pek çok gelişmiş ve gelişmekte olan ülkede bütçe açı̆̆ı GSYH'nın \%5'inin üzerine, borç seviyesi ise GSYH'nın \%60'ının üzerine çıkmıştır. Yüksek bütçe açıkları ve borç stoku sorunu mali sürdürülebilirlik konusundaki endişeleri artırmış ve genişletici para ve maliye tedbirlerinin hacminin krizin başlangıcına göre daha da daraltılması gerekmiştir. Bu durum, özellikle Euro Bölgesi'ndeki bazı ülkelerde var olan sosyal yardımlar ve verimlilik düşünün neden olduğu düşük büyüme dolayısıyla borcun GSYH'ya oranını düşürmeyi oldukça güçleştirmiştir. Özellikle Merkez Asya ve Avrupa ülkeleri için 2003-2007 arasında ortalama olarak \%10 olan büyüme oranları, krizle birlikte sıfıra düşmüş ve dış borç/GSYH oranları da \%42'den \%88'e yükselmiştir (Gooptu \& Braga, 2010: 209; Li vd., 2011: 249).

Küresel finansal kriz, ülkelere etkisi bakımından gelişmiş ve gelişmekte olan ülkeler arasında kesin bir ayrım yapmıştır. Bu bağlamda gelişmekte olan ülkeler, krize yüksek döviz rezervi, düşük borçluluk oranı gibi daha olumlu temel göstergelerle girerken ve krize karşı mali manevra imkanlarına sahipken, gelişmiş ülkeler ve özellikle Avrupa ve bazı Asya ülkeleri krize gelişmekte olan ülkelere göre daha kötü bir mali pozisyonda girmişlerdir. Krizin etkisine açık tüm ülkeler, krizin etkilerini azaltmak için bir dizi genişletici politikalar uygulamışlardır. Konjonktür karşıtı maliye politikası, faiz oranı indirimi, kredi genişlemesi ve uluslararası likidite desteği gibi politikalar bunlardan bazılarıdır. Krizden önce makroekonomik performansı iyi durumda olan ve krizin etkilerini azaltabilecek adımları atabilecek ekonomik güce sahip olan ülkeler daha hızlı ve geniş paketler açıklamışlardır. Mali pozisyonu zayıf olan, manevra alanı dar olan ülkelerin uyguladığı genişletici politikalar ise ülkeleri yüksek kamu borcu hatta bazı ülkelerde ise borç krizi ile yüz yüze getirmiştir (Van Doorn vd., 2011: 184). Bu konuya en güzel örnek ise Avrupa borç krizidir.

2008 krizi başlangıçta ABD’deki konut balonunun patlamasının ve özel sektör kredi genişlemesi sonucu olsa da, mali kurtarma paketleriyle birlikte bütçe açı̆̆ının patlamasına ve kamu borçlarının yükselmesine sebep olarak, özellikle Avrupa'da borç krizine dönüşmüştür (Schularick, 2012: 2). Küresel ekonomik ve finansal krizin sonucunda, gelişmiş ülkelerin kamu borçlarında keskin bir artış olmuştur. Bu durum, mali 
sürdürülebilirliğin devamı konusunda ve daha kapsamlı olarak da ekonomik ve finansal piyasalarda istikrarın sağlanması ve de sürdürülebilmesi konusunda endişelere neden olmuştur (Kumar \& Woo, 2010: 4). Reinhart ve Rogoff'un 2010 tarihli çalışmasına göre, 2007-2009 yılları arasında İzlanda, İrlanda, İspanya, ABD ve Birleşik Krallık (İngiltere)'da kamu borç stoku reel olarak yaklaşık \% 75 artmıştır. Büyük bir finansal kriz yaşamamış ülkelerde ise 2007 ila 2009 yılları arasında kamu borcundaki ortalama reel artış yaklaşık \%20'dir (Reinhart 6 Rogoff, 2010: 4). Kredi genişlemesinden en çok etkilenen İrlanda ve İspanya ile zaten yüksek borç/GSYH oranına sahip olan İtalya, Portekiz ve Yunanistan gibi ülkelerde ekonomik koşulların daha da kötüleşmesiyle birlikte sürdürülebilirlik tartışmaları iyice ayyuka çıkmıştır. Sürdürülebilirlik endişesinin artmasıyla birlikte, faiz oranları keskin bir şekilde yükselmiş ve kamu borç dinamikleri daha da bozulmuştur (Schularick, 2012: 2). Reinhart ve Rogoff (2009)'a göre, bankacılık krizi ile kamu borçları arasındaki düzenli artış ve temerrüde düşme riski arasında güçlü bir ilişki söz konusudur ve 2003-2006 döneminin aksine 2007-2009 döneminde kamu borçlarındaki artış, bazı ülkelerde uygulanan kurtarma paketlerinin doğrudan maliyetidir. Adı geçen yazarlara göre, finansal krizler bazı korkuları açığa çıkarmıştır. Krizin neden olduğu daralmayı sınırlamak için uygulanan konjonktür karşıtı maliye politikaları ile derin ve sürekli üretim kayıpları vergi açığına neden olmuş, kamu maliyesinde yaşanan olumsuzluklar ise borç krizini tetiklemiştir (Reinhart \& Rogoff, 2009: 3). Pek çok ülkede küresel krizle bağlantılı (krize karşı) kurtarma paketleri ve kamu gelirlerinde meydana gelen belirgin düşüş hem gelişmiş hem de gelişmekte olan piyasa ekonomilerini etkilemiştir (Reinhart \& Rogoff, 2010: 4).

\subsection{Krizin Gelişmiş Ülkelere Etkisi: Avrupa Borç Krizi}

Küresel kriz gelişmiş ve gelişmekte olan birçok ülkeyi etkilemiş olmakla birlikte, ABD ile oldukça sıkı finansal ve ekonomik ilişkiler içinde olan ülkeler krizin olumsuz etkilerine daha fazla maruz kalmıştır. ABD ile olan sıkı finansal ve ekonomik ilişkilerinin yanı sıra çoğunluğunu parasal birliğe dâhil olan ülkelerin oluşturduğu AB ülkelerinin kriz öncesi dönemde zayıf ekonomik performansa sahip olmaları, bu ülkelerin krizden etkilenmelerinin daha şiddetli olmasına neden olmuştur. Aslına bakılırsa, kriz öncesinde ekonomik büyüme rakamları oldukça olumlu seyretmiştir (Bkz. Tablo 3). Ancak pozitif büyüme rakamları her şeyin olumlu seyrettiği algısını yaymış, ekonomik büyümenin perde arkasındaki olumsuzluklar, Avrupa'nın krizden son derece sert bir şekilde etkilenmesine neden olmuştur. $\mathrm{Bu}$ durum, kriz öncesinde üzerinde fazla durulmayan Avrupa'nın borç yapısı ve ekonomik durumunun dengesizliğini gözler önüne sermiştir (Favaro vd., 2011: 228). Kriz öncesi var olan yüksek borçluluk, krizin ilk aşamasında (2007-2009) daha da artmıştır $^{5}$. Finansal sistemdeki aksaklıklar da ülkelerin

5 Krizin ilk yıllarında (2007-2009) Euro alanı ülkelerde borç/ GSYH oranı özel borçlarla ile birlikte tavan yapmiştır. Ispanya'da (sirasılyla özel ve devlet borcu) \%317'den \%334'e ve \%40'tan \%64'e; Fransa'da 
borçlarını ve ekonomik durumlarını olumsuz yönde etkilemiştir. Sadece krizden önceki zayıf ekonomik göstergeler değil, krizden sonra finansal sistemdeki aksaklıklar sonucu bankalara yapılan yardımlar (kaynak aktarımlarının) da ülkelerin ekonomik durumunun kötüye gitmesine ve borçlarının artmasına neden olmuştur.

Kamu borçlarındaki artışın kısa ve uzun dönemde ekonomi üzerinde olumsuz etkiler doğurduğu bilinmektedir. Artan kamu borçları, verimlilik ve ekonomik büyümede düşüşe yol açtığı gibi, sermaye birikimini de olumsuz yönde etkilemektedir. Küresel krizin olumsuz etkileri; uzun dönem faiz oranları, gelecekte artması olası saptırıcı vergiler, yüksek enflasyon, artan belirsizlikler ve krize duyarlılık üzerinden kendini göstermektedir. Kriz verimlilik, ekonomik büyüme ve sermaye birikimi aracılığıyla kamu borçlarını etkilediği gibi, kamu borçlarındaki artış da söz konusu değişkenlere önemli ölçüde etki etmektedir. Örneğin, ekonomik büyüme artan borçlardan olumsuz etkilendiğinde, risk primi yükselmektedir. Bu durum, borçlanma maliyetinde artışa neden olmaktadır. Borçlanma maliyetindeki artış orta ve uzun dönemde borç stokunda artışa neden olduğundan, mali sürdürülebilirlik konusunda endişeler artmaktadır. Sürdürülebilirlik konusundaki endişeler ise, gelecek hakkındaki belirsizlikleri ve dolayısıyla yatırımları (büyümeyi) olumsuz yönde etkilemektedir. (Kumar \& Woo, 2010: 4). Literatür, yüksek kamu borcunun uzun dönem faiz oranları üzerinden sermaye birikimi ve büyümeyi olumsuz etkilediğini, aynı zamanda yüksek borcun, konjonktür karşıtı maliye politikasının etkinliğini sınırlayarak ekonomik dalgalanmalara ve gelecekte düşük büyümeye neden olduğuna işaret etmektedir (Kumar \& Woo, 2010: 5). Bu durum ülkelerin uygulamaya koyduğu mali canlandırma paketlerinin yerini zamanla mali konsolidasyonu sağlamaya yönelik önlemlere bırakmasına neden olmakta, pek çok ülke makroekonomik istikrar içerisinde büyümenin sürdürülebilirliği konusunda içinden çıkılması zor bir açmazla karşı karşıya kalmaktadır. Tablo 3, kriz öncesi ve sonrası büyüme performansı hakkında bir fikir vermesi açısından önemlidir.

Tablo: 3

\section{Euro Alanı ve Seçilmiş Bazı Ülkelerde Reel Ekonomik Büyüme (GSYH) (\%)}

\begin{tabular}{|l|c|c|c|c|c|c|c|c|c|c|}
\hline Yillar-Ülkeler & 2005 & 2006 & 2007 & 2008 & 2009 & 2010 & 2011 & 2012 & 2013 & 2014 \\
\hline Euro Alanı & 1,7 & 3,2 & 3,0 & 0,5 & $-4,5$ & 2,0 & 1,6 & $-0,8$ & $-0,3$ & 0,9 \\
\hline Almanya & 0,7 & 3,7 & 3,3 & 1,1 & $-5,6$ & 4,1 & 3,7 & 0,7 & 0,3 & 1,6 \\
\hline Fransa & 1,8 & 2,5 & 2,3 & $-0,1$ & $-3,1$ & 2,0 & 2,1 & 0,2 & 0,7 & 0,2 \\
\hline Portekiz & 0,8 & 1,4 & 2,4 & 0,0 & $-2,9$ & 1,9 & $-1,8$ & $-4,0$ & $-1,1$ & 0,9 \\
\hline İrlanda & 6,3 & 6,3 & 5,5 & $-2,2$ & $-5,6$ & 0,4 & 2,6 & 0,2 & 1,4 & 5,2 \\
\hline İtalya & 0,9 & 2,2 & 1,7 & $-1,0$ & $-5,5$ & 1,7 & 0,5 & $-2,8$ & $-1,7$ & $-0,4$ \\
\hline Yunanistan & 0,6 & 5,7 & 3,3 & $-0,3$ & $-4,3$ & $-5,5$ & $-9,1$ & $-7,3$ & $-3,2$ & 0,7 \\
\hline İspanya & 3,7 & 4,2 & 3,8 & 1,1 & $-3,6$ & 0,0 & $-1,0$ & $-2,6$ & $-1,7$ & 1,4 \\
\hline
\end{tabular}

Kaynak: Eurostat, <http://ec.europa.eu/eurostat/tgm/table.do? tab=table\&init=1\&language $=e n \&$ pcode $=$ tec00115\&plugin $=1>$. 
Tablo 3'e göre, krizin başlangıç yılı olan 2007 yılına doğru AB ülkelerinin büyüme hızı yavaşlamış ve büyüme hızındaki düşüş, 2008 ve 2009 yıllarında en yüksek düzeye ulaşmıştır. Ancak her ülke için büyümeyi besleyen faktörler farklılık arz ettiğinden, büyüme oranlarındaki düşüş ve bunun ekonomik değişkenlere yansıması ülkeler açısından farklılık arz etmiştir. Dolayısıyla, Avrupa'daki tüm ülkelerin krize ekonomik olarak aynı olumsuz koşullarda girmediği söylenebilir. Özellikle PIIGS ülkeleri krizden daha çok olumsuz etkilenmişlerdir. Nitekim bu ülkelerin kriz öncesi ekonomik durumları da aslen pek iç açıcı değildir. Örneğin, Yunanistan, İrlanda, Portekiz ve İspanya krize yüksek cari açıkla girerken Almanya cari fazla ile girmiştir. Büyümenin dinamikleri de ülkeden ülkeye farklılık göstermiştir. Almanya ve İrlanda ihracata dayalı büyüme stratejisi izlerken, Yunanistan ve Portekiz'de büyüme özel tüketimdeki artı̧̧a, İspanya'da ise özel tüketim ve yatırımlardaki artışa dayanmıştır. Avrupa ülkelerinde, özellikle Portekiz ve Yunanistan'da özel ve kamu tasarruflarının azalması; yatırımları ve dolayısıyla da büyüme performansını olumsuz etkilemiştir (Favaro vd., 2011: 222).

Küresel krize, genişletici politikalarla cevap verilmesi neticesinde birçok ülkede kamu harcamaları artmıştır. Bütçe açıkları artan ülkeler, parasal birliğin sağladığı avantajla edinebildikleri ucuz kredilerle bu açıkları kapatmıştır. Parasal birliğe geçişle birlikte ülkeler arası ekonomik ve yapısal farklılıklar mali piyasalar tarafindan tam olarak fiyatlandırılamamıştır. Düşük kredibiliteye sahip ülkeler parasal birliğe dahil olmanın sağladığı kredibiliteden yararlanarak, olması gerekenden daha düşük maliyetle borçlanabilmiştir. Ortak parasal alanın sağladığı bedavacılık sorununun yanı sıra, ulusal paraların tedavülden kaldırılması da borç krizinin ortaya çıkmasında etkili olmuştur. Şöyle ki, parasal birlikle birlikte, Avrupa Merkez Bankası fiyat istikrarı hedefine odaklanırken; ekonomi politikasının diğer hedeflerini gerçekleştirmenin maliyeti maliye politikası üzerinde kalmıştır. Bu durum büyüme yanlısı politikalar izleyen ya da konjonktür karşıtı politikalar uygulama zorunluluğu ile karşı karşıya kalan ülkelerde bütçe açıları ve borç stoklarında artışa yol açmıştır. AB borç krizinin ortaya çıkmasında, bankacılık sistemine ilişkin düzenlemelerin ulusal hükümetlere bırakılması da etkili olmuştur. Ortak paraya geçişle merkezi para politikası uygulamasına karşın, parasal birliğe dâhil ülkeler bankacılık sistemi kaynaklı maliyetleri yüklenmeye devam etmişlerdir (Lane, 2012: 4950). Küresel krizle birlikte finans sektöründe meydana gelen kırılganlıkları azaltmaya yönelik önlemler, bankacılık sistemi kaynaklı doğrudan ve dolaylı birçok maliyeti de beraberinde getirmiştir. Bu sürecin sonucunda kamu borç yükü oldukça yüksek seviyelere çıkmıştır (Caruana \& Andjiev, 2012: 75). Diğer yandan bazı ülkelerde bankalara verilen yüksek miktarda yardım krizden sonra kamu borç yükünün artışına neden olmuştur. $\mathrm{Bu}$ durum özellikle İrlanda için geçerlidir. Dolayısıyla Avrupa'da kamu borç yükündeki artışın veya diğer bir deyişle kamu borç krizinin nedeninin genel olarak global finansal kriz ve bunun sonucunda finansal sistemdeki bozukluklar ve kriz öncesi dönemdeki yüksek borç stoku olduğu söylenebilir. Ülke borçlarının artışını hızlandıran diğer bir etken ise, krizin etkilerini bertaraf etmek adına uygulanan genişletici politikalardır (Favaro vd., 2011: 228). 
Düşen iç talebi ve istihdamı desteklemek için uygulanan genişletici politikalar, kamunun borç yükünü artırmıştır. Bu duruma ekonomik aktivitenin düşmesine paralel olarak vergi gelirlerinin düşmesi ve banka kurtarma paketleri de eklenince kamu borç yükü oldukça yüksek düzeylere çıkmıştır (Volz, 2012: 5). Mali genişleme önlemleri, 2008-09 yılında küresel ekonomik daralmanın yavaşlamasını sağlarken, pek çok ülkede ekonomik büyüme alanında gerçekleşen toparlanmayla bu önlemler gevşetilmiştir. Zamanla mali genişleme önlemlerinin yerini, mali konsolidasyon önlemleri almıştır. $\mathrm{Bu}$ nedenle, kriz sonrası dönemde uygulanan ekonomi politikaları biraz daha karmaşık bir görünüm arz etmiştir. Mali konsolidasyon, harcamalarda tasarruf yapmayı gerektirdiğinden, bu kesintinin başlangıç aşamasında ekonomik yeniden yapılanmanın hacmi sınırlanmış ve ülkelerin büyüme performansında düşük de olsa olumsuz etki meydana gelmiştir (Gooptu \& Braga, 2010: 215). Mali konsolidasyon önlemleri yürürlüğe konulurken, kriz koşullarını aşmanın tek yolu; işsizliği arttırıp üretimi düşürmek, kamu ve özel harcamaları daraltıp borçları ödeyebilir duruma gelmek olarak değerlendirilmiştir. $\mathrm{Bu}$ ise, devletlerin GSYH'sını daraltırken, yükselen faiz yükünü de giderek arttırmıştır ve borçları ödenemez noktaya getirmiştir. İrlanda, Portekiz, İspanya, İtalya, Yunanistan gibi ülkeler bu duruma girince, ayrıca toksik kâğıtlar ile banka bataklarının yükünü taşıyan Almanya, Fransa gibi devletler de mali açıdan sıkışmaya başlamışlardır. Çözüm ise, Avrupa Merkez Bankası'nın (ECB) ortak (Euro alanı) tahvil çıkarmasında aranmıştır. Finansal kriz gelişmiş ülkelerin finansal sisteminden kaynaklandığı için bu ülkeleri daha fazla etkilemiştir. Krize karşı alınan önlemlerin devlet borçlarına etkisi ise genişletici politika uygulayan hemen hemen tüm ülkelerde benzer sonuçlar doğurarak kamu borç yükünü arttırmıştır. Güçlü ve sürdürülebilir bir büyüme performansı yakalanamadığı için (Bkz. Tablo 3) mali konsolidasyon önlemleri, artan bütçe açığı ve dolayısıyla kamu borcunun seviyesini sınırlamada yetersiz ve etkisiz kalmıştır.

Tablo: 4

\section{Bazı Euro Alanı Ülkelerinde Kamu Borç Stoku/GSYH Oranı (\%)}

\begin{tabular}{|c|c|c|c|c|c|c|c|c|c|c|c|}
\hline Yıllar-Ülkeler & 2005 & 2006 & 2007 & 2008 & 2009 & 2010 & 2011 & 2012 & 2013 & 2014 & MK-BT \\
\hline Euro Alanı & 70,1 & 68,5 & 66,2 & 70,1 & 79,9 & 85,3 & 85,8 & 89,1 & 90,9 & 91,9 & 60 \\
\hline Almanya & 68,8 & 68 & 65,2 & 66,8 & 74,75 & 82,5 & 77,9 & 79,3 & 77,1 & 74,7 & 60 \\
\hline Fransa & 66,4 & 63,7 & 64,2 & 68,2 & 79,2 & 82,4 & 85,2 & 89,6 & 92,3 & 95 & 60 \\
\hline Portekiz & 67,7 & 69,4 & 68,4 & 71,7 & 83,7 & 94 & 108,2 & 125,8 & 129,7 & 130,2 & 60 \\
\hline İrlanda & 27,2 & 24,6 & 24,9 & 44,2 & 64,4 & 91,2 & 111,2 & 127,7 & 123,2 & 109,7 & 60 \\
\hline İtalya & 105,7 & 106,3 & 103,3 & 106,1 & 116,4 & 119,3 & 116,4 & 123,1 & 128,5 & 132,1 & 60 \\
\hline Yunanistan & 100 & 106,1 & 107,4 & 112,9 & 129,7 & 148,3 & 171,3 & 156,9 & 175 & 177,1 & 60 \\
\hline İspanya & 43,2 & 39,7 & 36,3 & 40,2 & 54 & 61,7 & 69,2 & 84,4 & 92,1 & 97,7 & 60 \\
\hline
\end{tabular}

* MK-BT; Avrupa Birliği üyesi veya üye olmak isteyen ülkeler için Maastricht Kriteri maksimum borç seviyesini göstermektedir. Kaynak: Eurostat, <http://epp.eurostat.ec.europa.eu/tgm/table.do? tab =table\&init=1\&plugin=1\& language $=e n \&$ pode $=$ tsdde410>.

Küresel krizin kamu borçlarına etkisini Tablo 4'den daha açık bir şekilde görmek mümkündür. Tablo 4'den de görüleceği üzere, İtalya ve Yunanistan'ın finansal krizden önceki yüksek borç seviyesi, krizle birlikte gelen borç krizinin habercisi olmuştur. Yüksek borç/GSYH oranı ile finansal krizin başladığı 2007 yılına giren bu ülkelerde, kamu harcamalarını artırarak krizin ekonomik sisteme etkisini azaltmak için uygulanan genişletici politikalar ve kurtarma paketleri neticesinde ülke borçları daha da artmıştır. 
Tablo 4, 2009'a gelindiğinde Euro alanının en büyük ve en gelişmiş dört ekonomisinde dahi kamu borcu/GSYH oranının, Euro anlaşmasının koyduğu (\%60) sınırını çok aştığını göstermektedir. Burada dikkat edilmesi gereken nokta İrlanda'nın durumudur. İrlanda, krizden önce düşük borç oranına sahipken krizden sonra borç/GSYH oranı hızla artmıştır. Örneğin söz konusu oran krizin başladığı yıl olan 2007 yılında \%44,2 iken 2012 yılında bu oran \%117,4' e çıkmıştır. Bunun nedeni genel olarak bankalara verilen yüksek kurtarma paketleridir. $\mathrm{Bu}$ bağlamda, İrlanda krizin neden olduğu finansal sistemdeki çöküş ve uygulanan genişletici politikaların kamu borçlarına etkisinin en güzel örneğini oluşturmaktadır. Dolayısıyla şu söylenebilir ki İrlanda batan bankaların, İspanya konut sektöründeki patlamanın, Yunanistan ise yüksek kamu harcamaları ve reformları geciktirmenin kurbanı olmuştur.

Küresel krizin ülke ekonomilerine etkisi, finansal sektörün ekonomi içerisindeki ağırlığına bağlı olarak değişiklik göstermiştir. Tagkalakis (2013)' e göre, 20 OECD ülkesinde 1990-2010 yılları arasında, finansal kriz ülkelerin borç stokunu GSYH'nın \%2.7-4.0 arasında değiştirmiştir. Finansal sektörün daha geniş olduğu ülkelerde ise bu oran \%4.2-5.3 arasında gerçekleşmiştir.

\section{Grafik: 2}

\section{Gelişmiş Ülkelerde Kriz Sonrası Borç Stoku ve Bütçe Açığındaki Değişme}

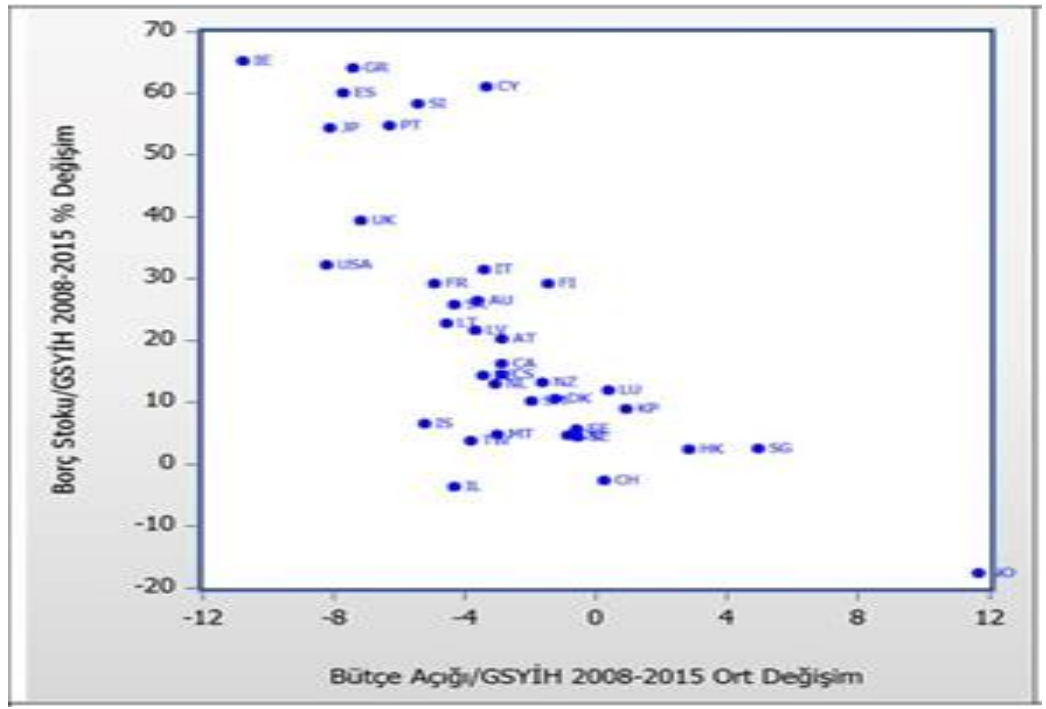

Kaynak: IMF, World Economic Outlook Database verilerinden yararlanılarak hazırlanmıştır.

Krizin en önemli sonuçlarından biri de, kamu finansmanı üzerinde olmuştur. Kurtarma paketleri, gelişmiş ülkelerin borçlarını görülmemiş ölçüde yükseltmiştir. Ulusal otoriteler bankacılık sektörünü desteklemeye çalıştığından, kamu kaynakları; bankaların 
sermaye yapısının güçlendirilmesine, toksik kağıtların satın alınmasına ve bankacılık sektörünü kurtarmaya yönelik diğer yardımlara yönlendirilmiştir. Bankacılık sektörünü kurtarmaya yönelik önlemlerin toplam maliyeti; Birleşik Krallık'ta GSYH'nın \%74'ü, ABD'de \%73'ü ve Euro alanında \%18 nispetine ulaşmıştır (Detragiache \& Ho, 2010: 3$4)^{6}$. Bankacılık sektörünü kurtarmaya yönelik önlemlere ekonomik büyümeyi yeniden tesis etmeye yönelik önlemlerin eklenmesiyle, krizin kamu maliyesine maliyeti daha da artmıştır. Gelişmiş ülkelerde kriz sonrası borç seviyesi ve bütçe açığındaki değişmenin gösterildiği Grafik 2'den de görüleceği üzere, kurtarma paketleri neticesinde 2008-2015 döneminde gelişmiş ülkelerde bütçe açı̆̆ 1 ortalama $\% 5$, borç seviyesi ise ortalama \%20-30 arasında, Avrupa çevre ülkelerinde ise ortalama \%60 seviyesinde yükselmiştir ${ }^{7}$.

Küresel krizin kamu borçlarına etkisi, kredi daralmasının kamu borçlanma maliyetine olan etkisi ile de kendisini göstermiştir. Finansal krizden sonraki kredi daralması da aslen Avrupa ülkelerini krizin ağırlaştığı dönemde etkilemiştir. Küresel krizin etkisini yoğun olarak hissettirdiği 2008 ve 2009 yıllarında kamu tahvil faizleri ve kredi temettü swaplarının primlerinde artış meydana gelmiştir. Ancak bu artışlar çok fazla bir oranda olmamış ve asıl yüksek artışlar 2009'dan sonra meydana gelmiştir. Dolayısıyla ülke risklerinin özellikle Yunanistan'ın yeni hükümetinin daha önceki hükümetin verileri çarpıttığı ve 2009 yılı bütçe açığının aslında daha fazla olduğunu açıklaması sonucu, ilgi borçların sürdürülebilirliğine yönelmiş ve bu durumun sonucunda Euro alanı çevre ülkelerinin borçlanma maliyetleri artmıştır (Volz, 2012: 3-4). Tagkalakis (2013), bozulan finansal koşullar ile (kredi daralması) borç oranındaki bozulma (artış) arasında pozitif ilişki olduğunu ve geri ödeme riski artıkça bu ilişkinin daha açık olduğunu ve nominal uzun dönemli faiz oranlarının artığını belirtmiştir.

Tablo 5, AB ülkelerinde 10 yıllık devlet tahvillerinin ortalama faiz oranını göstermektedir. Küresel krizin başlangıç yılı olarak kabul edilen 2007 yılında tahvil faiz oranları yükselmiştir. Krizin şiddetli hissedildiği 2008 ve 2009 yıllarında ise oran, krizin başlangıcına göre düşmüştür. Bunun nedeni, kredi derecelendirme kuruluşlarının Avrupa'da borç krizi başlamadan önce birçok Euro alanı ülkesinin kredi notunu artırmasıdır. Bu durum ülkelere yönelik risk algısını düşük tutmuştur. Düşük risk algısı anılan ülkelerin borçlanmalarını kolaylaştırmış, birçok ülkede yüksek borç oranlarının

6 Kriz öncesinde, 2007 yllında ABD'de borç seviyesi GSYH'nın \%62.3'ü seviyesinde iken, bu oran \%103.8'ine ulaşmıştır. Bu oran Japonya 'da \%172.1 iken, \%224.2 'sine ulaşmıştır.

7 Küresel kriz, 1990'll yıllar sonrasında yaşanan deflasyonist süreçten kurtulabilmek için sürekli genişletici politikalar uygulayan Japonya'yı gelişmiş ülkeler içerisinde en yüksek borç/GSYH oranına sahip ülke konumuna getirmişstir. Ancak, 2014 yll itibariyle kamu borç stoku GSYH'ye oraninın \%246 olduğu bu ülke; yurtiçi piyasalardan borçlanabilme imkânı, sıfira yakn reel faiz orant, yüksek tasarruf düzeyi ve bu sayede gerçekleşen düsü̈k borç çevirme maliyeti sayesinde artan kamu borç stoku borç krizine yol açmadan çevrilebilmiştir. Borç stokunu çevirmenin düşük maliyeti ve ülkeye özgü olumlu koşulların etkisiyle AB örneğinde olduğu gibi bir borç krizi yaşanmasa da, bu ülkede giderek artan borç stoku makroekonomik istikrarı tehdit eden bir seviyeye yükselmiştir (IMF, 2015). 
sürdürülebilir olduğu düşünülmüştür. Bunun sonucunda kredi notlarında bir indirimin yerine birçok ülkenin kredi notlarında artış görülmüştür. Fakat kredi derecelendirme kuruluşları çevre ülkelerdeki ekonomik dengesizlikleri değerlendirmede yetersiz kalmıştır. Daha da önemlisi, Euro Alanı'ndaki riski ve hatta özel sektör dengesini yansıtmakta da başarısız olmuşlardır (Nielsen, 2011: 135; Ulusoy \& Ela, 2014: 92). Bu noktada, kredi derecelendirme kuruluşları hem küresel krizin hem de $\mathrm{AB}$ borç krizinin en önemli nedenlerinden biri olmuşlardır. Küresel krizden sonra not indirimine maruz kalan ülkelerde ülke risk primleri artmış ve bu ülkeler için borçlanma daha maliyetli hale gelmiştir (ElArian, 2012: 34). Tablo 5'deki 2010 ve 2011 yılına ilişkin veriler ortalama faiz oranlarının arttığını ve borçlanma maliyetlerinin Avrupa çevre ülkeleri için yükseldiğini göstermektedir. Dolayısıyla, kredi derecelendirme kuruluşlarının Avrupa ülkelerinin çoğu için not indirimleri, bu ülkelerin borç yükünün artmasına neden olmuştur. Borç yükündeki artış faiz ödemelerine de yansımış, özellikle Avrupa borç krizi ile birlikte, başta PİIGS ülkeleri olmak üzere gelişmiş ülkelerde faiz ödemelerinin kamu harcamalarına oranı artmıştır. Gelişmiş ülkelerde borç faiz ödemelerinin kamu harcamalarına oranının gösterildiği Tablo 6'dan da görüleceği üzere, ABD, Kanada, İtalya, Japonya ve Yunanistan'da borç faiz ödemelerinin kamu harcamalarına oranı ele alınan dönem itibariyle dünya ortalamasının üzerinde seyretmiştir. Küresel kriz ve akabinde ortaya çıkan Avrupa borç krizi gelişmiş ülkelerde faiz ödemelerinin kamu harcamalarına oranının artırmıştır. Özellikle PİIGS ülkelerinde söz konusu oran, 2011 ve 2012 yıllarında dünya ortalamasının üzerine çıkmıştır.

Tablo: 5

\section{Avrupa Birliği ve PIIGS ülkelerinde On Yıllık Ortalama Tahvil Faiz Oranları}

\begin{tabular}{|c|c|c|c|c|c|c|c|c|c|c|}
\hline Ülkeler & 2005 & 2006 & 2007 & 2008 & 2009 & 2010 & 2011 & 2012 & 2013 & 2014 \\
\hline $\mathrm{AB}(28)$ & 3,74 & 4,12 & 4,58 & 3,98 & 3,97 & 4,19 & 4,25 & 2,97 & 3,03 & 1,50 \\
\hline $\mathrm{AB}(27)$ & 3,71 & 4,10 & 4,56 & 3,96 & 3,96 & 4,20 & 4,23 & 2,96 & 3,02 & 1,49 \\
\hline Euro Alanı & 3,40 & 3,85 & 4,36 & 3,73 & 3,64 & 4,12 & 4,52 & 3,08 & 2,96 & 1,34 \\
\hline Almanya & 3,34 & 3,77 & 4,21 & 3,05 & 3,14 & 2,91 & 1,93 & 1,30 & 1,80 & 0,59 \\
\hline Fransa & 3,38 & 3,81 & 4,35 & 3,54 & 3,48 & 3,34 & 3,16 & 2,01 & 2,33 & 0,92 \\
\hline Portekiz & 3,55 & 4,04 & 4,54 & 4,47 & 4,01 & 4,60 & 6,81 & 4,54 & 4,11 & 1,99 \\
\hline İrlanda & 3,36 & 3,76 & 4,45 & 4,57 & 4,88 & 8,45 & 8,70 & 4,67 & 3,48 & 1,31 \\
\hline İtalya & 3,55 & 4,04 & 4,54 & 4,47 & 4,01 & 4,60 & 6,81 & 4,54 & 4,11 & 1,99 \\
\hline Yunanistan & 3,57 & 4,04 & 4,53 & 5,08 & 5,49 & 12,01 & 21,14 & 13,33 & 8,66 & 8,42 \\
\hline İspanya & 3,37 & 3,82 & 4,35 & 3,86 & 3,81 & 5,38 & 5,53 & 5,34 & 4,13 & 1,78 \\
\hline
\end{tabular}

*Euro Area (EA); EA12-2006, EA13-2007, EA15-2008, EA16-2010, EA17-2013, EA18-2014.

* Veriler, Aralık ayı baz alınarak oluşturulmuştur.

Kaynak: Eurostat, $<$ http://ec.europa.eu/eurostat/tgm/table.do?tab=table\&init=1\&language $=$ en\&pcode $=$ teimf050\&plugin $=1>$.

Küresel krizin Avrupa borç krizine dönüşmesinde Avrupa'da bankacılık sektörüne yönelik destekler de etkili olmuştur. Avrupa'da bankalara verilen destekler yüzeyde bırakılıp derinliğine gidilmediği için, borç yükü azaltılamamış ve giderek ağırlaşmıştır. Buna Euro'nun bir egemen devlet parası olmaması ve diğer yetersizlikleri de 
eklenince ${ }^{8}$, Euro alanı krizi, hem Euro alanı içinde hem dışında "üsselleşerek" büyüyen etkiler yaratma yoluna girmiştir (Kazgan, 2013: 4). Avrupa borç krizinin temelindeki başka bir etmen, rekabet gücündeki gerilemedir. Küreselleşen dünyada, küresel pazardan pay alma yarışında küresel rekabet gücü önemli bir belirleyici güç haline gelmiştir. Küreselleşme ve liberalleşme sürecinin sonucunda artan uluslararası ticaret, rekabetçiliği küresel piyasada var olabilmenin önemli bir köşe taşına dönüştürmüştür.

Tablo: 6

\section{Gelişmiş Ülkelerde Borç Faiz Ödemelerinin Kamu harcamalarına Oranı (\%)}

\begin{tabular}{|l|c|c|c|c|c|c|c|c|c|}
\hline & 2004 & 2005 & 2006 & 2007 & 2008 & 2009 & 2010 & 2011 & 2012 \\
\hline Euro Alanı & $-2,31$ & $-1,32$ & $-1,06$ & $-0,48$ & $-0,87$ & $-0,45$ & $-0,32$ & $-0,21$ & 0,03 \\
\hline AB (27) & $-2,43$ & $-1,54$ & $-1,32$ & $-0,64$ & $-1,01$ & $-0,70$ & $-0,42$ & $-0,21$ & $-0,31$ \\
\hline ABD & 4,38 & 5,95 & 6,76 & 8,07 & 6,35 & 4,55 & 4,62 & 5,42 & 4,95 \\
\hline Japonya & - & 2,57 & 3,92 & 5,97 & 5,38 & 4,25 & 4,50 & 3,83 & 3,34 \\
\hline Kanada & 6,66 & 5,90 & 6,31 & 6,37 & 5,19 & 3,93 & 3,61 & 3,44 & 2,45 \\
\hline Fransa & $-2,31$ & $-1,32$ & $-1,06$ & 0,02 & 0,39 & $-0,38$ & $-0,59$ & $-0,22$ & $-0,89$ \\
\hline Almanya & $-2,21$ & $-1,26$ & $-0,58$ & 0,53 & 0,34 & 0,06 & $-0,51$ & $-0,21$ & $-0,99$ \\
\hline Yunanistan & 3,41 & 4,06 & 4,51 & 5,05 & 5,17 & 4,81 & 6,56 & 8,21 & 3,33 \\
\hline İrlanda & $-4,17$ & $-3,40$ & $-3,05$ & $-2,23$ & $-1,91$ & $-0,52$ & $-0,15$ & 1,84 & 3,17 \\
\hline İtalya & 4,11 & 4,79 & 4,86 & 6,44 & 6,58 & 4,88 & 4,89 & 5,72 & 6,47 \\
\hline İspanya & $-1,26$ & $-0,87$ & $-1,03$ & $-0,48$ & $-0,87$ & $-0,45$ & $-0,25$ & 1,20 & 1,23 \\
\hline Portekiz & $-1,73$ & $-1,10$ & 0,05 & 1,42 & 1,78 & 1,15 & 0,89 & 3,46 & 3,78 \\
\hline İngiltere & $-2,97$ & $-1,79$ & $-1,32$ & $-0,02$ & $-0,19$ & $-0,89$ & 1,27 & 2,01 & 0,85 \\
\hline Dünya & 7,90 & 6,81 & 6,34 & 5,47 & 5,42 & 5,01 & 5,20 & 5,39 & 5,88 \\
\hline
\end{tabular}

Kaynak: World Development Indicator Database,

$<$ http://databank.worldbank.org/data/reports.aspx?source=world-development-indicators $>, 22.12 .2015$.

Tablo: 7

\section{Bazı Avrupa ve PIIGS Ülkelerinin Küresel Rekabet Endeksi*}

\begin{tabular}{|c|c|c|c|c|c|c|c|c|}
\hline $\begin{array}{l}\text { Yıllar } \\
\text { Ülkeler }\end{array}$ & $\begin{array}{l}\text { 2006-2007 } \\
\text { (Sıra/Skor) }\end{array}$ & $\begin{array}{c}\text { 2007-2008 } \\
\text { (Sıra/Skor) }\end{array}$ & $\begin{array}{c}\text { 2008-2009 } \\
\text { (Sıra/Skor) }\end{array}$ & $\begin{array}{c}\text { 2009-2010 } \\
\text { (Sıra/Skor) }\end{array}$ & $\begin{array}{c}\text { 2010-2011 } \\
\text { (Sıra/Skor) }\end{array}$ & $\begin{array}{c}\text { 2011-2012 } \\
\text { (Sira/Skor) }\end{array}$ & $\begin{array}{c}\text { 2013-2014 } \\
\text { (Sıra/Skor) }\end{array}$ & $\begin{array}{l}\text { 2014-2015 } \\
\text { (Sira/Skor) }\end{array}$ \\
\hline Almanya & $8 / 5.58$ & $5 / 5.51$ & $7 / 5,46$ & $7 / 5,37$ & $5 / 5,39$ & $6 / 5,41$ & $4 / 5,51$ & $5 / 5.49$ \\
\hline Fransa & $18 / 5.31$ & $18 / 5.18$ & $16 / 5,22$ & $16 / 5,13$ & $15 / 5,13$ & $18 / 5,14$ & $23 / 5,05$ & $23 / 5.08$ \\
\hline Portekiz & $34 / 4.60$ & $40 / 4.48$ & $43 / 4,47$ & $43 / 4,40$ & $46 / 4,38$ & $45 / 4,40$ & $51 / 4,40$ & $36 / 4.54$ \\
\hline İrlanda & $21 / 5.21$ & $22 / 5.03$ & $22 / 4,99$ & $25 / 4,84$ & $29 / 4,74$ & $29 / 4,77$ & $28 / 4,92$ & $25 / 4.98$ \\
\hline Italya & $42 / 4.46$ & $46 / 4.36$ & $49 / 4,35$ & $48 / 4,31$ & $48 / 4,37$ & $43 / 4,43$ & $49 / 4,41$ & $49 / 4.42$ \\
\hline Yunanistan & $47 / 4.33$ & $65 / 4.08$ & $67 / 4,11$ & $71 / 4,04$ & $83 / 3,99$ & $90 / 3,92$ & $91 / 3,93$ & $81 / 4.04$ \\
\hline İspanya & $28 / 4.77$ & $29 / 4.66$ & $29 / 4,72$ & $33 / 4,59$ & $42 / 4,49$ & $36 / 4,54$ & $35 / 4,57$ & $35 / 4.55$ \\
\hline
\end{tabular}

* Küresel Rekabet Endeksi; kurumlar, ülkedeki uygulamalar, makroekonomik ortam, verimlilik, teknolojik hazırllk, ekonominin üretim seviyesi gibi bir dizi faktörlere göre belirlenmektedir. Uzun vadeli ekonomik büyüme için gerekli yapısal reformların belirlenmesi ve uygulanması skoru dolayıslyla siralamayı pozitif etkilemektedir. Kaynak: World Economic Forum, The Global Competitiveness Indexes, 2007, 2008, 2009, 2010, 2011, 2012, 2013, 2014, 2015.

8 Parasal birliğe dahil ülkelerde Maastricht kriterleri ile üye ülkelerin bütçe açıkları ve borç stoklarının disipline edilmesi hedeflenmişse de, mali yakınlaşma kriterlerini tutturamayan ülkelerde birliğe üye olarak alınmıştır. Birlik üyesi ülkelerde mali disiplinin tesis için büyüme ve istikrar paktı önlemleri hayata geçirilmiş olsa da, bu önlemelerin uygulanmasında karşılaşılan eksiklikler hem bütçe açı̆̆ hem de borç stoku düzeyinin Maastricht kriterlerinde öngörülen değerleri aşmasına neden olmuştur (Grennes \& Strazds, 2015). 
Tablo 7, Avrupa'da Almaya dışında küresel rekabetin üst düzeyde olduğu bir ülkenin olmadığını, Fransa'nın ise nispeten rekabetçi bir ülke olduğunu göstermektedir. Ülkeler arasında rekabetçiliğin oldukça farklılaştığı ve özellikle PIIGS ülkelerinin rekabette dünyanın gerisinde olduğu görülmektedir. Tablo 7, PIIGS ülkelerinde Euro alanının temel hedeflerinden biri olan rekabetçiliği yükseltme amacı ile tezat bir görüntü göstermektedir (Ulusoy \& Ela, 2014: 97). Bu durum, ülkelerin üretim seviyesindeki daralma, teknolojik yenilemenin yapılamaması ve kötü mali pozisyonun sonucu olduğundan bozulan kamu dengelerini iyileştirme açısından da onları güç duruma koymaktadır. $\mathrm{Bu}$ nedenle, ülkelerin borç seviyelerinin yüksek kalmasına ve yüksek maliyetlerle borçlanmalarına neden olmaktadır.

\subsection{Krizin Gelişmekte Olan Ülke Borçlarına Etkisi}

Küresel finansal krizden önce (2000-2007), gelişmekte olan ülkelerin makroekonomik göstergeleri gelişmiş ülkelere nazaran çok daha olumlu bir görünüm arz etmiştir (Alarcan vd., 2009). Krizden önceki dönemde birçok ülkede döviz rezervleri artmış, enflasyon düşmüş, bütçe ve cari ödemeler dengesi iyileşmiştir. Birçok ülkede ise borç oranları düşmüştür (Li vd., 2011: 249). Orta Doğu ve Asya ülkeleri; cari denge, döviz rezervi ve borç konusunda güçlü bir duruş sergilerken, Afrika ülkelerinde bu üç göstergeden sadece cari açık nispeten olumsuz bir seyir izlemiş, borç ve döviz rezervleri konusunda ise daha olumlu bir performans sergilenmiştir. Latin Amerika ve Karayip ülkeleri ise cari açık ve borçlanmadan kaçınmaya devam etmişlerdir (Griffith-Jones \& Ocampo, 2009: 10). Dolayısıyla kriz öncesi ekonomik koşulların olumlu seyretmesi, kredi bolluğu, ticaret hacmindeki ve emtia fiyatlarındaki artışlar yanında krizden önce gelişmekte olan ülkelerin yapmış olduğu yapısal reformlar ülkelerin finansal krizin başlangıcında ekonomik olarak güçlü bir duruş sergilemesine yol açmıştır.

Küresel kriz, ABD sınırlarını aşarak AB'de etkilerini hissettirmeye başladığında, dünyanın geri kalan kısmı krizden ya hiç etkilenmemiş ya da krizi kısa sürede (bir yılda) atlatabilmiştir. Yükselen piyasa ekonomileri (Çin, Hindistan gibi) başta olmak üzere, genelde Asya Kaplanları krizden hiç etkilenmemişlerdir; diğerleri (Türkiye, Brezilya gibi) ise etkilenseler de kısa sürede atlatmışlardır (Abreu vd., 2009: 3). Genel itibariyle gelişmekte olan ülkeler krizi gelişmiş ülkelerden daha az zararla atlatmışlardır. Gelişmekte olan ülkelerin hemen hemen hiç biri finansal bir çöküş yaşamamıştır. Bu ülkelerin büyüme performansları dünya ortalamasının ve üst gelir seviyesindeki ülkelerin çok üzerinde seyretmiştir (Cömert \& Çolak, 2013: 1-2). Yani, gelişmekte olan ülkeler 2008 küresel krizinde geçmişteki krizlere benzer bir yıkımla karşılaşmamışlardır.

Bu durum, "birbirinden kopuş" (decoupling) tanımı ile ifade edilmiştir (Kazgan, 2013: 6). Gelişmekte olan ülkeler, geçmiş on yıllara kıyasla bugün dünya ekonomisine daha fazla entegre olmasına karşın, kriz bu ülkeleri gelişmiş ülkeler kadar etkilememiştir. Üstelik krizin gelişmiş ve gelişmekte olan ülkeleri etkileme mekanizması da farklı kanallar aracılığıyla gerçekleşmiştir. Gelişmekte olan ülkelerin krizden etkilenmesi, daha çok gelişmiş ülkelerin talep daralması aracılığıyla gerçekleşmiştir. Küresel kriz, gelişmekte 
olan ülkelerin finansal sistemlerinden doğmadığından başlangıçta gelişmekte olan ülkeleri ve geçiş ekonomilerini çok etkilememiştir. Hatta, krizin başlangıcında, gelişmekte olan ülkelerde reel ekonominin krizin yıkıcı etkilerinden hasarsız kurtulacağı ve bu ülkelerdeki büyümenin dünya ekonomisini su üstünde tutacağı (destekleyeceği) beklentisi hakim olmuştur (Abreu vd., 2009: 3; Kazgan, 2013: 7). Dolayısıyla, başlangıçta, küresel krizden gelişmekte olan ülkeler daha az etkilenmişlerdir (Abreu vd., 2009: 3). Geçmiş krizlerden farklı olarak, gelişmekte olan ülkeler kendi sınırları dışında meydana gelen (ABD'de) ve doğası gereği etki edemedikleri bir krizin mağduru haline gelmişlerdir (Gurtner, 2010). Gelişmekte olan ülkelerin böyle bir durumla karşı karşıya kalmasında; uluslararası ekonomik ilişkilerin geçmişle kıyaslanamayacak bir ölçüde artması ve hem gelişmiş ve hem de gelişmekte olan ülke ekonomilerinin küresel sisteme giderek daha fazla entegre olması etkili olmuştur'.

Gelişmekte olan ülkeler bazı etkileri gecikmeli olarak yaşasa da, krizden finansal ve ekonomik anlamda etkilenmişlerdir. Gelişmekte olan ülkelerin krizden etkilenme biçimi gelişmiş ülkelerden farklı olmuştur. Küresel kriz gelişmiş ülkeleri daha çok finansal piyasalar aracılığıyla etkilerken, gelişmekte olan ülkeleri daha çok reel kesim aracılığıyla etkilemiştir. Finansal etki ise ya kısa sürmüş (örneğin borçlanma faizleri sadece kısa bir dönem için artmış) ya da kimi ülkelere hiç uğramamıştır (Serieux, 2009: 8). Küresel krizle birlikte, gelişmiş ülkelerde mal ve hizmet talebi keskin şekilde düşmeye başlayınca, gelişmekte olan ülkelerin ihracat fiyatları ve ihracat hacimleri de düşmüştür. $\mathrm{Bu}$ durum başlangıçta, gelişmekte olan ve geçiş ekonomilerinde ihracatçı endüstrilerde üretim ve istihdamda şiddetli daralmaya neden olmuş ve hıla diğer endüstrilere de yayılmıştır. Bu nedenle, küresel krizin gelişmekte olan ülkeler üzerindeki etkisi esasen ihracat ve sermaye akımları yoluyla gerçekleşmiştir (Serieux, 2009: 8; Abreu vd., 2009: 3). Gelişmiş ülkelerin dış ticareti dolayısıyla ithalat talebindeki azalma, gelişmekte olan ülkelerin ihracatını azaltmış ve ihracat gelirlerinde azalma meydana gelmiştir. Söz konusu azalma emtia fiyatlarındaki düşüşle daha da artmıştır. Yani, küresel kriz, gelişmekte olan ülke ekonomilerini; dış ticaret, kredi kanalı ve yatırımlar üzerinden olumsuz etkilemiştir (SDE, 2012). Belirtilen faktörlere ilave olarak, miktar olarak çok büyük olmasa da bazı ülkeler için önemli yeri olan işçi dövizleri de krizden sonra azalma sürecine girmiş, sermaye akımları azalmıştır (Bkz. Tablo 2). Bu nedenle, büyüme aynı gelişmiş ülkelerdeki gibi gelişmekte olan ülkelerde de keskin şekilde düşmüştür (Bkz. Tablo 8). Kriz nedeniyle, başlangıçta ortaya çıkan kredi daralması sonucu sermaye akımları azalmış; küresel ticaretteki daralmadan gelişmekte olan ülkeler de etkilenmiştir (Bkz. Tablo 2, Grafik 1). $\mathrm{Bu}$ durum, büyüme rakamlarına da yansımıştır. 
Tablo: 8

Bazı Gelişmekte Olan Ülkelerde GSYH Büyüme Oranları (\%)

\begin{tabular}{|l|c|c|c|c|c|c|c|c|c|c|}
\hline Ülkeler & 2005 & 2006 & 2007 & 2008 & 2009 & 2010 & 2011 & 2012 & 2013 & 2014 \\
\hline Rusya & 6,4 & 8,2 & 8,5 & 5,2 & $-7,8$ & 4,5 & 4,3 & 3,4 & 1,3 & 0,6 \\
\hline Çin & 11,3 & 12,7 & 14,2 & 9,6 & 9,2 & 10,4 & 9,5 & 7,8 & 7,7 & 7,4 \\
\hline Hindistan & & 9,3 & 9,8 & 3,9 & 8,5 & 10,3 & 6,6 & 5,1 & 6,9 & 7,4 \\
\hline Brezilya & 3,2 & 4,0 & 6,1 & 5,2 & $-0,3$ & 7,5 & 3,9 & 1,8 & 2,7 & 0,1 \\
\hline Meksika & 3,0 & 5,0 & 3,1 & 1,4 & $-4,7$ & 5,1 & 4,0 & 4,0 & 1,4 & 2,1 \\
\hline Endonezya & 5,7 & 5,5 & 6,3 & 6,0 & 4,6 & 6,2 & 6,2 & 6,0 & 5,6 & 5,0 \\
\hline Malezya & 5,3 & 5,6 & 6,3 & 4,8 & $-1,5$ & 7,4 & 5,2 & 5,6 & 4,7 & 6,0 \\
\hline G. Afrika & & 5,6 & 5,4 & 3,2 & $-1,5$ & 3,0 & 3,2 & 2,2 & 2,2 & 1,5 \\
\hline Türkiye & 8,4 & 6,9 & 4,7 & 0,7 & $-4,8$ & 9,2 & 8,8 & 2,2 & 4,1 & 2,9 \\
\hline
\end{tabular}

Kaynak: World Bak, <http://data.worldbank.org/indicator/NY.GDP.MKTP.KD.ZG?page=1>.

Tablo 8'den görüldüğü üzere, küresel kriz öncesinde gelişmekte olan ülkelerde büyüme rakamları oldukça yüksek düzeyde seyretmiştir. Krizin, gelişmiş ülkelerin ticaret hacminde neden olduğu daralma ve artan risk algısı ile birlikte çoğu gelişmekte olan ülke bu olumsuzluklardan etkilenmiştir. Sonuçta, ekonomik etki kendini göstermiş ve 2009 yılında birçok ülkede negatif büyüme meydana gelmiştir. Mali manevra imkanı (yüksek döviz rezervleri, cari fazla) yüksek olan Çin, Hindistan, Endenozya gibi ülkelerde büyüme kriz sonrasında da pozitif kalmaya devam etmiş, diğer ülkelerde ise ekonomiler küçülmüştür. Büyümedeki durgunluk, kişi başına gelirin düşmesine, bütçe açığının, ticaret ve ödemeler dengesinin bozulmasına, döviz rezervlerinin azalmasına, enflasyonun artmasına neden olmuştur. Dolayısıyla krizden önceki olumlu hava krizden sonra tersine dönmeye başlamıştır.

Krizin gelişmekte olan ülkelere etkisi daha çok ekonomik yolla olsa da, faizlerdeki artışın etkisinin de göz ardı edilmemesi gerekir. Küresel krizin etkisi ile oluşan panik havasında riskten kaçış ve kredi sıkışıklığı, gelişmekte olan ülkeler için borçlanma faizlerini arttırmıştır. Dolayısıyla borçlanma kısa bir dönem de olsa krizden sonra daha maliyetli hale gelmiştir. Yani, küresel kriz ülkelerin uluslararası piyasalardan borçlanma marjını yükseltmiştir. Faizlerin yükselmesi ile borçlanmada yaşanan olumsuz durum; yükselen piyasa ekonomilerinin küresel finansal sisteme bağımlı olmalarından dolayı bu ülkelerin borçlanma maliyetini artırmıştır (Louis vd., 2009). Döviz kurunun artması, uygulanan genişletici politikalar, borçlanma faizlerindeki yükselişler gibi nedenlerle gelişmekte olan ülkelerde borçlar artmıştır ${ }^{10}$. Ancak bu durum çok uzun sürmemiş, Mart 2009'dan sonra faiz oranları düşme eğilimine girmiştir. Diğer yandan krizle birlikte artan kredi sıkışıklığı sonucu artan döviz kurları daha istikrarlı hale gelmiştir (Van Doorn vd., 2011: 180). Yani, küresel kriz, Avrupa'dakine benzer bir biçimde borç krizine neden olmamıştır.

10 Krizden hemen sonra 2008 yllında gelişmekte olan ülkelerde kamu borcu 176 milyar dolar artmıştır (UNCTAD, 2009: 7). 


\section{Grafik: 3}

\section{Gelişmekte Olan Ülkelerin Dış Borç Yükümlülüklerinde Ortalama Faiz Oranı*}

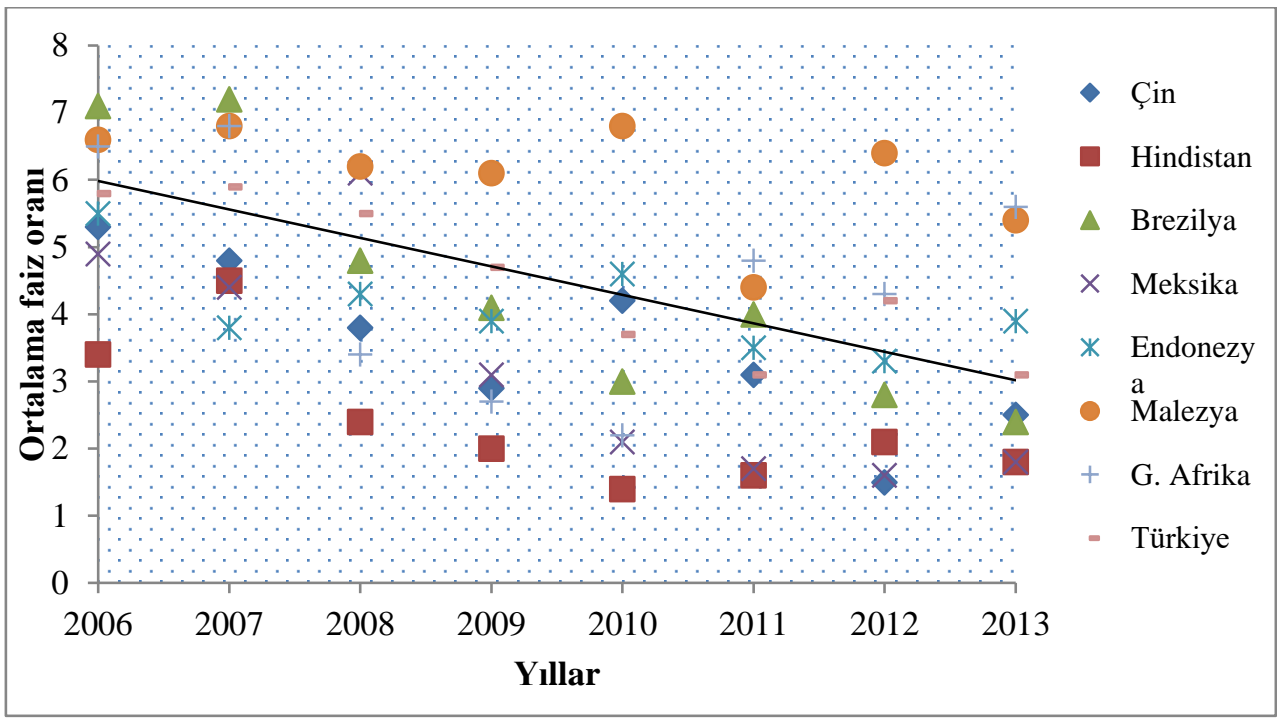

*Yll içerisinde kamuca alınan veya garanti verilen borçlara ilişkin faizlerin ortalamasıdır. Kaynak: <http://data.worldbank.org/indicator/DT.INR.DPPG>.

Grafik 3, küresel kriz öncesindeki olumlu finansal koşulların etkisiyle; gelişmekte olan ülkelerin dış borç yükümlülüklerine ilişkin faiz oranlarının düştüğünü göstermektedir. Kriz neticesinde, oluşan likidite sıkışıklığı ve artan risk algısı 2009 yılında faiz oranlarını yükseltmiştir. Fakat krize karşı piyasaya likidite enjekte etme politikalarının etkisi, gelişmekte olan ülkelerin mali esneklikleri ve risk algısının düşmesiyle birlikte gelişmekte olan ülkelerin dış borç yükümlülüklerine ilişkin faiz oranları yeniden düşüşe geçmiştir. Gelişmekte olan ülkelerin olumlu koşullar altında finansman sağlaması; krizin başlangıcında bu ülkelerin mali manevra yapma kabiliyetlerinin yüksek olması, yani bu ülkelerin krize karşı direnç mekanizmalarına sahip olmasıyla açıklanabilir.

Küresel krizin gelişmekte olan ülkeleri gelişmiş ülkeler kadar olumsuz etkilememesi ve bu ülkelerin nispeten olumlu koşullar altında borçlanmalarına karşın, kriz sonrası oluşan ekonomik durumu düzeltmeye yönelik genişletici politikalar, yüksek kamu bütçe açı̆̆ına sebebiyet vermiş ve buna paralel olarak da gelişmekte olan ülkelerin devlet borçlarında da artışlar görülmüştür. Kriz öncesi pozitif büyümenin 2008 yılında da devam etmesi nedeniyle, borç/GSYH oranında 2008 yılında da oransal olarak düşüş devam etmiştir (UNCTAD, 2009: 10). Krizin gelişmekte olan ülkeler üzerindeki asıl etkisi, 2009 yllından sonra görülmüştür. Ancak, bu etki Avrupa'daki gibi bir borç krizine evrilmemiştir. Literatürde gelişmekte olan ülkelerin krize karşı görece başarılı performansı; mali manevra imkânlarını güçlendiren cari açık sorunlarını büyük ölçüde 
çözmelerine, büyüme dinamiklerine, yüksek rezerv birikimlerine ve dalgalı kur rejimi uygulama temelli olan finansal istikrar politikalarına atfedilmektedir. 2008 küresel krizinden sonra uygulanan genişletici politikalar ise, hemen hemen tüm ülkelerde borçlanma seviyesini yükseltmiştir (Tablo 9). İlave olarak, artan borç ve yeni finansman ihtiyacı pek çok gelişen ekonomi için mali alanı da daraltmıştır.

Tablo: 9

\section{Gelişmekte Olan Ülkelerde Kamu Borç Stokunu GSYH'ye Oranı (\%)}

\begin{tabular}{|c|c|c|c|c|c|c|c|c|c|c|c|}
\hline Ülkeler & 2005 & 2006 & 2007 & 2008 & 2009 & 2010 & 2011 & 2012 & 2013 & 2014 & AB-BT* \\
\hline Rusya & 16,7 & 9,9 & 7,2 & 6,5 & 8,7 & 9,1 & 9,3 & 12.7 & 13.4 & 13.0 & 60 \\
\hline Çin & - & - & - & 17.0 & 17.7 & 33.5 & 28.7 & 26.1 & 22.4 & 20.2 & 60 \\
\hline Hindistan & 61,2 & 59,1 & 56,5 & 56,1 & 54,3 & 50,4 & 48,5 & 66.6 & 66.7 & 65.3 & \\
\hline Brezilya & - & 55,8 & 57,4 & 56,6 & 60,0 & 52,2 & 52,8 & 68.2 & 66.3 & 66.7 & \\
\hline Meksika & - & - & - & 42.8 & 43.9 & 42.2 & 43.3 & 43.3 & 46.5 & 48.1 & 60 \\
\hline Endonezya & 47,3 & 39,0 & 35,2 & 33,1 & 28,4 & 26,0 & 26,2 & & & & 60 \\
\hline Malezya & 42,1 & 40,6 & 40,1 & 39,8 & 50,8 & 51,1 & 51,6 & & & & 60 \\
\hline G.Afrika & - & - & - & 27.2 & 31.6 & 35.3 & 38.8 & 42.1 & 45.2 & 47.3 & 60 \\
\hline Türkiye & 52,7 & 51,5 & 44,4 & 44,7 & 53,6 & 50,9 & 45,9 & 36.2 & 35.8 & 35.9 & 60 \\
\hline GPE*** & - & - & - & 23,0 & 27,8 & 27,9 & 26,5 & 24,9 & 24,9 & 23,9 & 60 \\
\hline
\end{tabular}

* AB-BT; Avrupa Birliği Maastricht Kriteri çerçevesinde üye ülkelerin veya üye olmak isteyen bir ülkenin borç seviyesini göstermektedir.

** GPE: Emerging Market Economies. Çin ve Meksika 'ya ilişkin veriler ile 2011 sonrast veriler IMF, Fiscal Monitor, 2014'den alınmıştır.

Kaynak: World Bank, <http://data.worldbank.org/indicator/GC.DOD.TOTL.GD.ZS/countries/TR? display $=$ default $>$.

Gelişmekte olan ülkelerde kamu borç stokunun GSYH'ye oranının gösterildiği Tablo 9'dan da görüldüğü üzere, küresel krizin gelişmekte olan ülkelerin borç stoku üzerinde etkisi sınırlı olmuştur. Gelişmekte olan ülkelerde kamu borç stokunun GSYH'ye oranı 2008 yılında devam eden ekonomik büyümenin etkisiyle önemli bir değişikliğe uğramazken, 2009 yılındaki genişletici politikalar sonucu kamu harcamaları artmış ve harcamalardaki artışın yol açtığı bütçe açıkları anılan ülkelerin borç stokunu artırmıştır. Örneğin, kriz karşıtı politikalar çerçevesinde kamu harcamalarını arttıran Brezilya ve Malezya'nın borç oranlarındaki sıçramalar diğer ülkelere nazaran daha fazla olmuştur. Dolayısıyla genişletici politikaların hacmi, borçlanma üzerinde de büyük oranda etkili olmuştur. 2009 yılında gerçekleşen borç stoku artışında, genişletici politikaların yanı sıra borçlanma faizlerindeki artış da etkili olmuştur. Ancak tekrar belirtmekte yarar vardır ki, gelişmekte olan ülkelerin borç stokundaki artış düzeyi, gelişmiş ülkelerinkine nazaran daha sınırlı kalmıştır. Bu durumun oluşmasına gelişmekte olan ülkelerin krizden önceki güçlü ekonomik görünümü de katkı sağlamıştır.

Grafik 3'te gelişmekte olan ülkelerde 2008-2015 döneminde bütçe açığ ve borç stokunun GSYH'ye oranında meydana gelen değişim gösterilmektedir. Grafik 3'ten de görüleceği üzere, ele alınan dönemde gelişmekte olan ülkelerin borç seviyesi ortalama \%25 artarken, bütçe açığı ortalama \%2-4 arasında yükselmiştir. Küresel kriz sonrasında gelişmekte olan ülkelerin borç seviyesi ve bütçe açığı artmakla birlikte, bu ülkelerde gerçekleşen bütçe açığı ve borç stoku GSYH oranı değişimleri, gelişmiş ülkelere oranla oldukça düşük düzeylerde seyretmiştir. 
Grafik: 3

Gelişmekte Olan Ülkelerde Kriz Sonrası Borç Seviyesi ve Bütçe Açığındaki Değişme

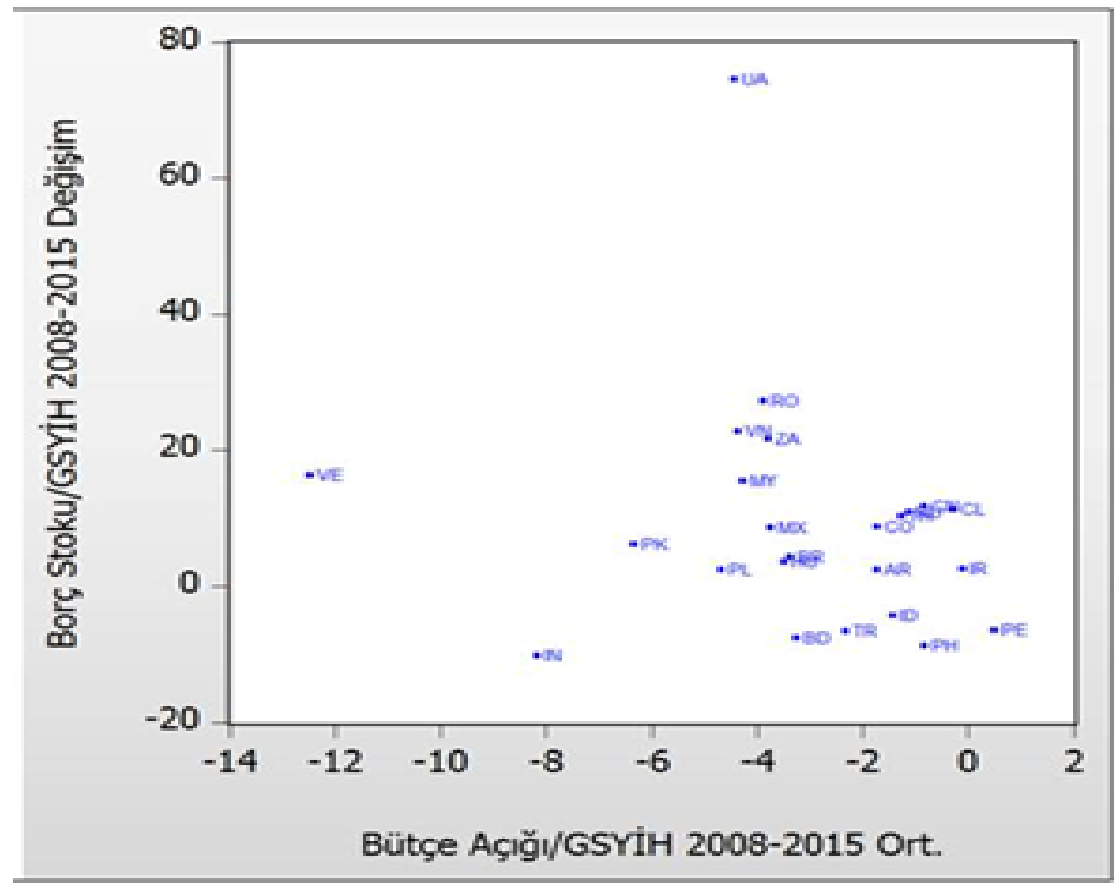

Kaynak: IMF, World Economic Outlook Database verilerinden yararlanılarak hazırlanmıştır.

Küresel krizin gelişmekte olan ülkelere etkisi, kredi derecelendirme kuruluşlarının verdiği değerleme notlarındaki değişim aracılığıyla da açıklanabilir. Finansal ve ekonomik bütünleşmeyle birlikte, ülke kredi notları küresel sermaye akımını yönlendiren en önemli unsurlardan biri haline gelmiştir (Haspolat, 2015: ii). Bu çerçevede, ülkelerin mali yükümlülüklerini zamanında ve eksiksiz olarak yerine getirebilme kapasitelerini değerlendiren kredi derecelendirme kuruluşlarının değerlendirmeleri, gelişmekte olan ülkelerin borçlanma imkânları açısından önem taşımışıır. Fakat küresel krizle birlikte kredi derecelendirme kuruluşlarına duyulan güven, başta $\mathrm{ABD}$ olmak üzere gelişmiş ülkelerin finansal riskini değerlendirmede yetersiz kaldıklarından sarsılmıştır.

Tablo 10 incelendiğinde, gelişmekte olan ülkelerin yatırım yapılabilir kredi değerliliğine sahip olduğu anlaşılmaktadır. Gelişmekte olan ülkelerin küresel kriz öncesi ve sonrasında sahip oldukları olumlu makroekonomik koşullar, bu ülkelere yönelik risk algısının gelişmiş ülkelere oranla daha düşük olmasını sağlamıştır. Gelişmekte olan ülkelere yönelik düşük risk algısının etkisiyle, kriz öncesinde bu ülkelerin kredi notları yükselmiştir. Ticaret hacmindeki genişleme, potansiyel büyüme seviyelerine yakın 
büyüme, düşük bütçe açığı, dış borç seviyesinin düşük olması ve yüksek döviz rezervleri kriz öncesinde gelişmekte olan ülkelerin kredi notunun yükselmesine neden olmuştur. Bu durum, gelişmekte olan ülkelerin borçlanma marjını artırdığı gibi bu ülkelere olan yatırımcı ilgisini de artırmış ayrıca borç seviyesini yükseltmiştir. Krizden sonra ise, ticaret hacmindeki daralmaya karşın bu ülkelerin küresel kriz nedeniyle veya Avrupa borç krizi nedeniyle ekonomilerine gelen bir şoka karşı mali dengeyi tekrar kurma kapasitesinin olması, dış finansman ihtiyacının düşük olması ve rezerv birikimi nedeniyle ülkelerin kredi notu yüksek kalmaya devam etmiştir. Bu da, ülkelerin borç seviyelerini yükseltmiştir.

Tablo: 10

\section{Gelişmekte Olan Ülkeler Kredi Notları (Moody’s Yerel Para Cinsinden)}

\begin{tabular}{|c|c|c|c|c|c|c|c|c|c|c|}
\hline Ülkeler & 2006 & 2007 & 2008 & 2009 & 2010 & 2011 & 2012 & 2013 & 2014 & 2015 \\
\hline Rusya & $\mathrm{Baa} 2$ & Baa2 & Baa1 & Baa1 & Baa1 & Baa1 & Baa1 & Baa1 & $\mathrm{Baa} 2$ & $\mathrm{Ba} 1$ \\
\hline Çin & - & $\mathrm{A} 1$ & A1 & A1 & $\mathrm{Aa} 3$ & $\mathrm{Aa} 3$ & $\mathrm{Aa} 3$ & $\mathrm{Aa} 3$ & $\mathrm{Aa} 3$ & $\mathrm{Aa} 3$ \\
\hline Hindistan & $\mathrm{Ba} 2$ & $\mathrm{Ba} 2$ & $\mathrm{Ba} 2$ & $\mathrm{Ba} 2$ & Ba1 & Baa3 & $\mathrm{Baa} 3$ & Baa3 & $\mathrm{Baa} 3$ & $\mathrm{Baa} 3$ \\
\hline Brezilya & $\mathrm{Ba} 2$ & Ba1 & Ba1 & $\mathrm{Baa} 3$ & Baa3 & Baa2 & Baa2 & Baa2 & Baa2 & Baa3 \\
\hline Meksika & Baal & Baa1 & Baa1 & Baa1 & Baal & Baa1 & Baa1 & Baa1 & $\mathrm{A} 3$ & $\mathrm{~A} 3$ \\
\hline Endonezya & B1 & $\mathrm{Ba} 3$ & $\mathrm{Ba} 3$ & $\mathrm{Ba} 2$ & $\mathrm{Ba} 2$ & Ba1 & Baa3 & Baa3 & Baa3 & $\mathrm{Baa3}$ \\
\hline Malezya & $\mathrm{A} 3$ & $\mathrm{~A} 3$ & $\mathrm{~A} 3$ & $\mathrm{~A} 3$ & A3 & A3 & $\mathrm{A} 3$ & $\mathrm{~A} 3$ & $\mathrm{~A} 3$ & $\mathrm{~A} 3$ \\
\hline Güney Afrika & $\mathrm{A} 2$ & $\mathrm{~A} 2$ & $\mathrm{~A} 2$ & A3 & A3 & A3 & Baa1 & Baa1 & Baa2 & Baa2 \\
\hline Türkiye & $\mathrm{Ba} 3$ & $\mathrm{Ba} 3$ & $\mathrm{Ba} 3$ & $\mathrm{Ba} 3$ & $\mathrm{Ba} 2$ & $\mathrm{Ba} 2$ & Ba1 & $\mathrm{Baa} 3$ & $\mathrm{Baa} 3$ & $\mathrm{Baa} 3$ \\
\hline
\end{tabular}

Not: Kredi dereceleri yılsonu (2015 yılı için Eylül ayl) oluşan dereceyi göstermektedir.

Kaynak: Moody's, <https://www.moodys.com/researchandratings/market-segment/sovereign-supranational//005005/4294966293/4294966623/-1/0/-/0/-/-/en/global/rr>.

Tablo: 11

Gelişmekte Olan Ülkelerde Borç Faiz Ödemelerinin Kamu harcamalarına Oranı (\%)

\begin{tabular}{|c|c|c|c|c|c|c|c|c|c|}
\hline Ülke Adı & 2004 & 2005 & 2006 & 2007 & 2008 & 2009 & 2010 & 2011 & 2012 \\
\hline Düşük Gelirli ülkeler & v.y. & v.y. & v.y. & v.y. & $-2,07$ & $-1,32$ & $-1,17$ & $-1,05$ & v.y. \\
\hline Orta gelirli ülkeler & 2,66 & 3,64 & 3,14 & 2,33 & 2,21 & 2,20 & 1,70 & 1,29 & 0,65 \\
\hline Düşük orta gelirli ülkeler & 4,30 & 4,04 & 3,90 & 4,61 & 4,28 & 5,08 & 5,08 & 4,64 & v.y. \\
\hline Yüksek orta gelirli ülkeler & v.y. & v.y. & 0,45 & $-0,50$ & 0,74 & 1,40 & 1,32 & $-0,05$ & $-0,40$ \\
\hline Brezilya & 11,38 & 16,83 & 19,89 & 19,16 & 18,95 & 17,10 & 15,97 & 17,49 & 15,28 \\
\hline Hindistan & 17,74 & 16,57 & 16,23 & 16,73 & 14,31 & 14,36 & 13,08 & 12,89 & 13,58 \\
\hline Endonezya & 9,28 & 5,75 & 6,55 & 6,00 & 4,26 & 5,64 & v.y. & v.y. & v.y. \\
\hline Malezya & 4,30 & 5,26 & 5,47 & 5,24 & 3,07 & 4,19 & 5,23 & 4,45 & 3,71 \\
\hline Rusya & $-2,84$ & $-1,98$ & $-3,05$ & $-3,63$ & $-3,67$ & $-3,55$ & $-3,64$ & $-3,45$ & $-3,83$ \\
\hline Güney Afrika & 3,66 & 4,05 & 3,51 & 3,20 & 2,27 & 2,10 & 2,49 & 2,62 & 2,47 \\
\hline Türkiye & v.y. & v.y. & v.y. & v.y. & 10,29 & 7,80 & 6,29 & 4,33 & 3,60 \\
\hline Dünya & 7,90 & 6,81 & 6,34 & 5,47 & 5,42 & 5,01 & 5,20 & 5,39 & 5,88 \\
\hline
\end{tabular}

Kaynak: World Development Indicator Database,

$<$ http://databank.worldbank.org/data/reports.aspx?source=world-development-indicators $>, 22.12 .2015$.

Gelişmekte olan ülkelerde borç faiz ödemelerinin kamu harcamalarına oranının gösterildiği Tablo 11'den de görüleceği üzere, küresel krizin faiz ödemelerine etkisi gelişmiş ülkelerle kıyaslandığında nispeten daha düşük olmuştur. Ele alınan dönem itibariyle, Rusya'da borç faiz ödemelerinin kamu harcamalarına oranı dünya ortalamasının altında seyrederken, Brezilya ve Hindistan'da söz konusu oran dünya ortalamasının oldukça üzerinde seyretmiştir. Düşük gelirli ülkelerin borçlanma olanaklarının sınırlı oluş nedeniyle, bu ülkelerde borç faiz ödemelerinin kamu harcamalarına oranı sınırlı düzeyde kalırken, bu ülkelerin kişi başına düşen geliri arttıkça faiz ödemelerinin kamu harcamaları 
içerisindeki payı da azalmıştır. Söz konusu ülkelerde borç faiz ödemelerinin kamu harcamalarına oranı genel olarak dünya ortalamasının üzerinde seyretse de, gelişmiş ülkelerin aksine bu ülkelerdeki genel eğilim borç faiz ödemelerinin kamu harcamalarına oranının azalması ve dünya ortalamasına yaklaşmasıdır.

Küresel kriz öncesi dönemdeki likidite bolluğu ve kriz sonrası dönemde gelişmekte olan ülkelerin nispeten olumlu ekonomik performansı bu ülkelere yönelik borç akışlarını artırmış ve gelişmekte olan ülkelerin borç seviyesi yükselmiştir. Bu ülkelerden, küresel rekabet gücü nispeten yüksek olan Çin'in borç seviyesi düşmüştür. Yine, küresel rekabet gücü yükselen Türkiye'nin de borç seviyesindeki düşüş devam etmiştir. Diğer ülkelerde ise, borç seviyesi nispeten istikrarlı bir görünüm arz etmiştir.

Tablo: 12

\section{Bazı Gelişmekte Olan Ülkelerinin Küresel Rekabet Endeksi}

\begin{tabular}{|c|c|c|c|c|c|c|c|c|}
\hline $\begin{array}{l}\text { Yıllar } \\
\text { Ülkeler }\end{array}$ & $\begin{array}{c}2006-2007 \\
\text { (Sıra/Skor) }\end{array}$ & $\begin{array}{c}\text { 2007-2008 } \\
\text { (Sıra/Skor) }\end{array}$ & $\begin{array}{c}2008-2009 \\
\text { (Sıra/Skor) }\end{array}$ & $\begin{array}{c}\text { 2009-2010 } \\
\text { (Sıra/Skor) }\end{array}$ & $\begin{array}{c}2010-2011 \\
\text { (Sira/Skor) }\end{array}$ & $\begin{array}{c}\text { 2011-2012 } \\
\text { (Sira/Skor) }\end{array}$ & $\begin{array}{c}\text { 2013-2014 } \\
\text { (Sira/Skor) }\end{array}$ & $\begin{array}{l}\text { 2014-2015 } \\
\text { (Sira/Skor) }\end{array}$ \\
\hline Rusya & $62 / 4.08$ & $58 / 4.19$ & $51 / 4.31$ & $63 / 4.15$ & $63 / 4.24$ & $67 / 4.20$ & $64 / 4.25$ & $53 / 4.37$ \\
\hline Çin & $54 / 4.24$ & $34 / 4.50$ & $30 / 4.70$ & $29 / 4.74$ & $27 / 4.84$ & $29 / 4.83$ & $29 / 4.84$ & $28 / 4.89$ \\
\hline Hindistan & $43 / 4.44$ & $48 / 4.33$ & $50 / 4.33$ & $49 / 4.30$ & $51 / 4.33$ & $59 / 4.32$ & $60 / 4.28$ & $71 / 4.21$ \\
\hline Brezilya & $66 / 4.03$ & $72 / 3.99$ & $64 / 4,13$ & $56 / 4.23$ & $58 / 4.28$ & $48 / 4.40$ & $56 / 4.33$ & $57 / 4.34$ \\
\hline Meksika & $58 / 4.18$ & & $60 / 4.23$ & $60 / 4.19$ & $66 / 4.19$ & $53 / 4.36$ & $55 / 4.34$ & $61 / 4.27$ \\
\hline Endenozya & $50 / 4.26$ & $54 / 4.24$ & $55 / 4,25$ & $54 / 4.26$ & $44 / 4.43$ & $50 / 4.40$ & $38 / 4.53$ & $34 / 4.57$ \\
\hline Malezya & $26 / 5.11$ & $21 / 5.10$ & $21 / 5.04$ & $24 / 4.87$ & $26 / 4.88$ & $25 / 5.06$ & $24 / 5.03$ & $20 / 5.16$ \\
\hline G. Afrika & $45 / 4.36$ & $44 / 4.42$ & $45 / 4,41$ & $45 / 4.34$ & $54 / 4.32$ & $52 / 4.37$ & $53 / 4.37$ & $56 / 4.35$ \\
\hline Türkiye & $59 / 4.14$ & $53 / 4.25$ & $63 / 4,15$ & $61 / 4.16$ & $61 / 4.25$ & $43 / 4.45$ & $44 / 4.45$ & $45 / 4.46$ \\
\hline
\end{tabular}

Kaynak: World Economic Forum, The Global Competitiveness Indexes, 2007, 2008, 2009, 2010, 2011, 2012,

$2013,2014,2015$

Bugün, gelişmekte olan ülkelere (124 ülke) gerçekleşen borç akışının \%92'sinin en büyük 20 gelişmekte olan ülkeye olduğu söylenebilir. Söz konusu oranın 2005 yılında \%50’lerde olduğu düşünüldügünde (Watts, 2014), küresel krizle birlikte gelişmekte olan düşük gelirli ülkelerin borçlanmasının hemen hemen imkânsız hale geldiği ve uluslararası kreditörlerin daha çok düşük risk primi taşıyan ülkelere borç vermeyi tercih ettiği söylenebilir. Bir diğer ifadeyle, küresel krizin ortaya çıkardığı koşullar, uluslararası kreditörlerin, risk algısını değiştirmiştir. Sermaye daha çok getiri elde edeceği yere değil, kredinin geri dönebileceği bölgelere yönelmiştir. Yaşanan süreçte makroekonomik performansı nispeten olumlu olan gelişmekte olan ülkeler uluslararası fonlara daha kolay erişebilme olanağına sahip olmuştur. Bu durum, anılan ülkelerin borç stokunda artışa yol açmıştır. Gelişmekte olan ülkelerin borç stokundaki bu artışın, sürdürülebilirlik açısından sorun oluşturmaması ve risk algısının yükselmemesi için dünyanın en büyük gelişmekte olan piyasa ekonomilerinin rekabet gücünü artırması gerekmektedir. Fakat Tablo 12, bu ülkelerin küresel rekabet gücünü artırmada güçlüklerle karşıya olduklarını göstermektedir. Borç seviyesi, \%60'ın altında olsa da bu düşük seviyeyi destekleyen rekabet gücü söz konusu değildir. 


\section{Sonuç}

Küreselleşme, ülkeler arasındaki ekonomik ve finansal etkileşimi arttırdığından krizlerin bulaşıcılığı ve etkileri çok çabuk yayılabilmekte ve diğer ülkeleri çeşitli kanallarla etkileyebilmektedir. Öyle ki, küreselleşmeyle birlikte ülke ekonomilerinin giderek daha fazla birbirine entegre olması, 1929 krizi ile karşılaştırıldığında 2008 krizinin daha küresel ölçekte etkileri olan bir kriz olmasına yol açmıştır. Küresel kriz, gelişmiş ülke kaynaklı olup tüm ülkeleri az ya da çok etkisi altına almıştır. ABD'de konut sektöründe başlayan krizin etkileri, bu ülke ile sınırlı kalmamıştır. ABD ile sıkı ekonomik bağları olan gelişmiş ülkeleri de, derinden sarsmıştır. Küresel krizin gelişmiş ülkelere etkisi, özellikle bankacılık sistemi üzerinden olmuştur. Kriz, gelişmiş ülkelerin borç seviyelerinin oldukça yüksek seviyelere yükselmesine neden olmuştur. İlave olarak, tüketim kalıplarının değişmesi, ihracat kanalları üzerinden gelişmekte olan ülkeleri etkilemiş ve onların büyümelerini olumsuz yönde etkilemiştir. Hatta bazı ülkelerin kamu borcu üzerinden temerrüde düşmesine neden olmuştur. Krizden önce zayıf bir görüntü çizen ve büyüme oranları ile bu durumu gölgeleyen Avrupa ülkeleri, krizle birlikte bozulan uluslararası şartlar nedeniyle hızla borç batağına girmiştir. Küresel krizde, kredi derecelendirme kuruluşlarının doğru fiyatlama yapamaması ve piyasa riskini ölçememelerinin de etkisi olmuştur. Krize yüksek kredi notu ile yakalanan ülkelerin risk primi, olması gerekenden düşük gösterilmiştir. Çoğunluğunu $\mathrm{AB}$ üyesi ülkelerin oluşturduğu bir grup ülkenin kredi notları, bu ülkelerin gerçek riskini göstermekten uzak belirlenmiştir. Kredi derecelendirme kuruluşlarının doğru fiyatlama yapamaması ve piyasa riskini doğru olarak ölçememesi sonucunda birçok ülke düşük risk primi ve uygun maliyetle aşırı borçlanma yapabilmişlerdir. Dolayısıyla ülke kredi risklerinin yanlış fiyatlandırılması, Avrupa ülkelerinin borç krizini tetikleyici unsurlarından biri olmuştur.

Krizden önce ekonomik durumları daha iyi olan gelişmekte olan ülkeler krize karşı daha hızlı ve etkin politika uygulayabilmişler ve krizden daha az etkilenmişlerdir. Gelişmekte olan ülkelerin de borç oranlarında önemli sayılabilecek artışlar gerçekleşmiştir. Ancak, bu ülkeler Avrupa'daki gibi bir borç krizi yaşamamışlardır. Küresel krizin gelişmekte olan ülkeleri nispeten daha az etkilemesinde, bu krizin geçmişte yaşanan krizlerin aksine gelişmiş ülke merkezli olması ve ilk etkilerini finansal sektör aracılığıyla göstermesi de etkili olmuştur. Bu nedenle, küresel ekonomiye daha az entegre olan ülkelerin krizden daha az etkilendiği ve küreselleşmenin zararlı yönü olan krizlerin bulaşıcı etkisinden bir anlamda korunabildikleri söylenebilir.

Küresel finansal krizin kamu borçlarını artırdığg 2007-2009 döneminde, büyüme oranları da bundan negatif etkilenmiştir. Özellikle PIIGS ülkeleri kamu borcunun yükselttiği temerrüde düşme riski ile karşı karşıya kalmışlar ve dolayısıyla krizin odağında olmaya devam etmişlerdir. Yani, Avrupa ülkelerinin karşı karşıya olduğu borç sorunları bu bölgedeki ülkelerde krizin göreli olarak daha uzun sürmesinde etkili olmuştur. Buna karşın, gelişmekte olan ülkelerde krizden sonra borç seviyesinde bir yükselme olsa da kriz öncesi olumlu mali pozisyon borç krizine düşmelerini önlemiştir. Küresel finansal krize 
karşı uygulanan genişletici politikalar, tüm ülkelerde borç seviyesini yükseltmiş ve bu açıdan çalışmanın hipotezini destekler sonuçlar ortaya çıkmıştır.

Bugün, ülkelerin borç yükümlülüklerini karşılayabilmeleri ve gelecekte kamu maliyelerinin karşı karşıya olduğu riskleri minimize edebilmeleri borç yönetim stratejisi geliştirebilmelerine bağlıdır. Bu stratejinin başarılı olabilmesi, ülkelerin kredibilitelerini en azından orta vadede yükseltmelerine ve yükümlülüklerini izleme ve yönetebilmeleri için ülkenin kurumsal kapasitesini geliştirmelerine bağlıdır. Kriz dönemlerinde dışsal şoklardan kaynaklanan kırılganlığ 1 hafifletmek amacıyla alınan önlemlerin doğru ve etkili olabilmesi için aktarım kanallarının iyi anlaşılması önem arz etmektedir. Gelişmekte olan ülkeler; değişen koşullara karşı var olan esnekliklerine karşın düşük büyüme, düşük emtia fiyatları ve güçlü dolardan kaynaklanan finansal kırılganlıklarını ortadan kaldırmadıkça mali sürdürülebilirlik tehlikeye düşecektir. Reel GSYH'daki büyüme, yüksek çıtı büyümesi, yatırımlardaki artış yanında dış borç/GSYH seviyesi, kamu borcu/GSYH düzeyi, kişi başına gelirdeki artış, kurumsal kalite ve doğrudan yabancı yatırım akışı küresel krizin etkisini bertaraf etmede önemli unsurlardır.

\section{Kaynaklar}

Abreu, M.P. \& M. Agarwal \& S. Kadochnikov \& M. Mikic \& J. Whaley \& Y. Yonding (2009), The Effects of The World Fnancial Crisis on Developing Countries: An Initial Assessment, CIGI Task Force on Developing Countries, <http://www.cigionline.org/sites/default/files/Task_Force_1.pdf>, 24.08.2015.

Alarcan, D. \& S. Grififth-Jones \& J.A. Ocampo (2009), "How Does The Financial Crisis Affect Developing Countries", International Policy Center for Inclusive Growth One Pager, No.81, <http://www.ipc-undp.org/pub/IPCOnePager81.pdf>, 04.09.2015.

Audiguier, C. (2012), "The Impact of the Global Financial Crisis on the Least Developed Countries", FERDI Working Paper, No.50, <http://www.ferdi.fr/sites/www.ferdi.fr/ files/publication/fichiers/Ferdi-DT50-C.Audigier_WEB.pdf>, 06.09.2015.

Baily, N.M. \& R.E. Litan \& M.S. Johnson (2008), "The Origins of the Financial Crisis”, Business and Publicy Policy at Brookings Fixing Finance Series, Paper 3, 1-47.

Boorman, J. (2009), "The Impact of the Financial Crisis on Emerging Market Economies: The Transmission Mechanicsm, Policy Response and Lessons", Emerging Markets Forum Discussion Draft, 1-16. <http://www.emergingmarketsforum.org/papers/pdf/ 2009-EMFGlobalBoorman_Financial_Crisis.pdf>, 10.09.2015.

Brok, E. \& W. Langen (2012), "Sustainable Growth For Europe: The Four Crisis and A Call For Reform", Europan Wiew, 11, 189-199.

Caruna, J. \& S. Andjiev (2012), "Sovereign Credithworthiness and Financial Stability: An International Perspective", Financial Stability Review, 16, 71-85.

Cömert, H. \& S. Çolak (2013), "Gelişmekte Olan Ülkelerdeki Kriz Sırası ve Sonrasındaki Trendleri Açıklamakta "Güvenli Liman Faktörü" ve Finansal Şokların Boyutunun Önemi: Türkiye Örneği, Türkiye Ekonomi Kurumu, Tartışma Metni, 2013/10, 1-32.

De Tombe, D. (2013), "The Actors of the Credit Crisis Reflected by the Compram Methodology", CEJOR (2013) 21:1-29, DOI 10.1007/s10100-011-0215-6. 
Detragiache, E. \& G. Ho (2010), "Responding to Banking Crises: Lessons from Cross-Country Evidence". IMF Working Paper, 18, 1-33.

El-Arian, M. (2012), "When Western Sovereign Risk is in Play", Financial Stability Review, 16, 2936.

Eser, L.Y. \& M. Ela (2014), “Avrupa Borç Krizi: Nasıl, Neden ve Nereye?, Eskişehir Osmangazi Üniversitesi İktisadi ve İdari Bilimler Fakültesi Dergisi, 10(1), 209-232.

Eurostat, <http://ec.europa.eu/eurostat/tgm/table.do?tab=table\&init=1\&language=en \&pcode= tec00115\&plugin=1>, 11.09.2015.

Eurostat, <http://epp.eurostat.ec.europa.eu/tgm/table.do?tab=table\&init=1\&plugin=1\&language= en\&pcode $=$ tsdde410>, 11.09.2015.

Favado, E. \& Y. Li \& J. Pradelli \& R. Van Doorn (2011), “Europe's Crisis: Origins and Policy Challenges", in: Carlos A. Primo Braga \& Gallina A. Vincelette (Eds.) Sovereign Debt and Financial Crisis, The World Bank, Washington, 221-239, http://dx.doi.org/10.1596/ 9780821384831_CH09.

Grennes, T. \& A. Strazds (2015), “Government Debt in Japan and Euro Area: Actions Speak Louder than Words", Roubini Economonitor, <http://www.economonitor.com/blog/2015/11/ government-debt-in-japan-and-euro-area-actions-speak-louder-than-words>, 22.12.2015.

Griffith-Jones, S. \& J.A. Ocampo (2009), “The Financial Crisis and Its Impact on Developing Countries", International Policy Centre For Inclusive Growth Working Paper, 53, 1-20.

Gooptu, S. \& C.A.P. Braga (2010), "Debt Management and the Financial Crisis", in: The Day After Tomorrow: A Handbook on the Future of Economic Policy in the Developing World, Eds: Otaviano Canuto \& Marcelo Giugale, 207-217, <http://siteresources.worldbank.org/ EXTPREMNET/Resources/C12TDAT_207-218.pdf>, 18.09.2015.

Gurtner, B. (2010), "The Financial and Economic Crisis and Developing Countries", International Development Policy [Online], 1(2010), <http://poldev.revues.org/144>, DOI: 10.4000/poldev.144.

Haffner, M. (2008), "Subsidization as Motor to Residental Mortgage Securitization in the US", Journal of Housing and the Built Environment, 23(4), 337-351.

Haspolat, F.B. (2015), “Ülke Kredi Notlarının Belirleyicileri: Türkiye'nin Kredi Notunun Ülke Karşılaştırmalı Analizi”, T.C. Kalkınma Bakanlığı Uzmanlık Tezi, Ekonomik Modeller ve Stratejik Araştırmalar Genel Müdürlüğü.

Hernandez, L. \& B. Gamara (2011), "Debt Sustainability and Debt Distressin the Wake of the Ongoing Financial Crisis: The Case of IDA-Only African Countries", in: Carlos A. Primo Braga \& Gallina A. Vincelette (Eds.) Sovereign Debt and Financial Crisis, The World Bank, Washington, 129-172, http://dx.doi.org/10.1596/9780821384831_CH06.

IMF (2009), The State of Public Finances: Outlook and Medium-Term Policies After the 2008 Crisis, Prepared by the Fiscal Affairs Department, 1-51.

IMF (2015), Japan Article IV Consultation-Press Release; Staff Report; And Statement By The Executıve Director For Japan, IMF Country Report No. 15/197, 1-51.

Kazgan, G. (2013), “2008 Krizi Üsselleşirken Türkiye'nin Sürdürülemez Büyüme Modeli”, Türkiye Ekonomi Kurumu Tartışma Metni 2013/4, 1-40.

Koepke, R. (2014), "Fed Policy Expectations and Portfolio Flows to Emerging Markets”, IIF Working Paper, 1-37.

Kumar, M.S. \& J. Woo (2010), “Public Debt and Growth”, IMF Working Paper-WP/10/174, 1-46. 
Karakurt, B. \& T. Akdemir (2016), "Küresel Finansal Krizinin Devlet Borçlarına Etkisi: Gelişmiş ve Gelişmekte Olan Ülkeler Açısından Bir Değerlendirme”, Sosyoekonomi, Vol. 24(29), 225-255.

Lander, G.H. \& K. Barker \& M. Zabelina \& T.A. Williams (2009), "Subprime Mortgage Tremors: An International Issue", International Advances in Economic Research, 15(1), 1-16.

Lane, P.R. (2012), “The European Sovereign Debt Crisis”, Journal of Economic Perspectives, 26 (3), 49-68.

Li, Yuefen \& R. Olivares-Caminal \& U. Panizza (2011), "Avoiding Avoidable Debt Crises: Lessons from Recent Defaults”, in: Carlos A. Primo Braga \& Gallina A. Vincelette (Eds.) Sovereign Debt and Financial Crisis, The World Bank, Washington, 243-272, http://dx.doi.org/10.1596/9780821384831_CH06.

Louis, K. \& N. Leonce \& R. Taufik (2009), "Impact of the Global Financial and Economic Crisis on Africa", African Development Bank Group Working Paper Series, 96, 1-35.

Meyn, M. \& J. Kennan (2009), "The Implications of the Global Financial Crisis for Developing Countries' Export Volumes and Values", ODI Working Paper, 305, 1-89.

Moody's, <https://www.moodys.com/researchandratings/market-segment/sovereign-supranational//005005/4294966293/4294966623/-1/0/-/0/-/-/en/global/rr>, 13.10.2015.

Nissanke, M. (2009), The "Global Financial Crisis and the Developing World: Transmission Channels and Fall-outs for Industrial Development", United Nation Indistrial Development Organization Research and Statistics Branch Working Paper, 06/2009, 164 ,

<https://www.unido.org/fileadmin/user_media/Publications/RSF_DPR/WP062009_Eboo k.pdf>, 20.10.2015.

Nielsen, E.F. (2011), "The European Crisis: A View from the Market”, in: Franklin Allen \& Elena Carletti \& Giancarlo Corsetti (Eds.), The Eurozone with or without Sovereign Default, Philadelphia, USA: FIC Press, 133-138.

Reinhart, C.M. \& K.S. Rogoff (2009), "The Aftermath of Financial Crises”, NBER Working Paper Series -Working Paper, 14656, 1-13.

Reinhart, C.M. \& K.S. Rogoff (2010), "Growth in a Time of Debt", NBER Working Paper Series, Working Paper No:15639, 1-25.

Schularick, M. (2012), "Public Debt and Financial Crises in the Twentieth Century", Freie Universitat Berlin, School of Business \& Economics Discussion Paper, 1-24.

Serieux, J. (2009), The Impact of Global Financial and Economic Crises on the Development Prospects of the Lanclocked Developing Countries, UN-OHRLLS Report, 1-38, <http://unohrlls.org/UserFiles/File/Publications/LLDC/Financial_Crisis_LLDC.pdf>, 18.09.2015.

Stratejik Düşünce Enstitüsü (SDE) (2012), AB Krizi ve Türkiye’ye Olası Yansımaları, SDE Analiz.

Tagkalakis, A. (2013), "The Effects of Financial Crisis on Fiscal Positions", European Journal of Political Economy, 29, 197-213, doi:10.1016/j.ejpoleco.2012.11.002.

Ulusoy, A. \& M. Ela (2014), “Avrupa Borç Krizi ve Türkiye İçin Öneriler”, HAK-IŞ̧ Uluslararası Emek ve Toplum Dergisi, 3(7): 77-112.

Ulusoy, A. \& T. Akdemir \& B. Karakurt (2013), 'Küresel Kriz ve Avrupa Birliği'nin Kriz Karşıt1 Maliye Politikalarının Etkinliği', Küresel Kriz ve Maliye Politikalarl, 28. Türkiye Maliye Sempozyumu, 22-26 May1s 2013, 247-286.

UNCTAD (2009), The Impact of Financial and Economic Crisis on Debt Sustainabilityin Developing Countries, UNCTAD Secreteriat Note, <http://unctad.org/en/docs/ gdsdmfasmisc20091_en.pdf>, 06.10.2015. 
Van Doorn, R. \& V. Suri \& S. Gooptu (2011), "Do Middle-Income Countries Still Have the Ability to Deal with the Global Financial Crisis", in: Carlos A. Primo Braga \& Gallina A. Vincelette (Eds.) Sovereign Debt and Financial Crisis, The World Bank, Washington, 173-195, http://dx.doi.org/10.1596/9780821384831_CH06.

Volz, U. (2012), "Lessons of the European Crisis for Regional Monetary and Financial Integration in East Asia", ADBI Working Papers, 347, <http://www.adbi.org/files/2012.02.21.wp347.lessons.european.crisis.east.asia.pdf>, 15.10.2015.

Watts, M.F. (2014), Debt Data: How Debt Inflows Differ among Developing Countries, $<$ http://blogs.worldbank.org/opendata/debt-data-how-debt-inflows-differ-amongdeveloping-countries>, 10.10.2015.

World Economic Forum, The Global Competitiveness Indexes, 2007, 2008, 2009, 2010, 2011, 2012, 2013, 2014, 2015.

World Bank, International Debt Statistics, 2013, <http://data.worldbank.org/sites/default/files/ids2013.pdf>, 17.11.2015.

World Bank, International Debt Statistics, 2015, <http://data.worldbank.org/sites/default/files/ids2015.pdf>, 17.11.2015.

World Bank, <http://data.worldbank.org/indicator/NY.GDP.MKTP.KD.ZG?page=1>, 11.10.2015.

World Bank, <http://data.worldbank.org/indicator/DT.INR.DPPG>, 13.11.2015.

World Bank, <http://data.worldbank.org/indicator/GC.DOD.TOTL.GD.ZS/countries/TR? display $=$ default $>, 26.11 .2015$. 
Karakurt, B. \& T. Akdemir (2016), "Küresel Finansal Krizinin Devlet Borçlarına Etkisi: Gelişmiş ve Gelişmekte Olan Ülkeler Açısından Bir Değerlendirme”, Sosyoekonomi, Vol. 24(29), 225-255. 